OPEN ACCESS

Edited by:

Karen L. Bacon,

University of Leeds, United Kingdom

Reviewed by:

Marlow G. Pellatt,

Parks Canada Agency, Canada

Debra Willard,

United States Geological Survey,

United States

*Correspondence:

S. Yoshi Maezumi

s.y.maezumi@exeter.ac.uk

${ }^{\dagger}$ Deceased

Specialty section: This article was submitted to

Paleoecology,

a section of the journal

Frontiers in Ecology and Evolution

Received: 30 March 2018

Accepted: 05 July 2018

Published: 03 August 2018

Citation:

Maezumi SY, Robinson M, de Souza J, Urrego $D H$, Schaan $D$, Alves $D$ and Iriarte J (2018) New Insights From Pre-Columbian Land Use and Fire Management in Amazonian Dark Earth

Forests. Front. Ecol. Evol. 6:111. doi: 10.3389/fevo.2018.00111

\section{New Insights From Pre-Columbian Land Use and Fire Management in Amazonian Dark Earth Forests}

\author{
S. Yoshi Maezumi ${ }^{1 *}$, Mark Robinson ${ }^{1}$, Jonas de Souza ${ }^{1}$, Dunia H. Urrego ${ }^{2}$, \\ Denise Schaan ${ }^{3+}$, Daiana Alves ${ }^{1}$ and Jose Iriarte ${ }^{1}$ \\ ${ }^{1}$ Department of Archaeology, College of Humanities, University of Exeter, Exeter, United Kingdom, ${ }^{2}$ Department of \\ Geography, College of Life and Environmental Sciences, University of Exeter, Exeter, United Kingdom, ${ }^{3}$ Department of \\ Anthropology, Federal University of Pará, Belém, Brazil
}

Anthropogenic climate change driven by increased carbon emissions is leading to more severe fire seasons and increasing the frequency of mega-fires in the Amazon. This has the potential to convert Amazon forests from net carbon sinks to net carbon sources. Although modern human influence over the Earth is substantial, debate remains over when humans began to dominate Earth's natural systems. To date, little is known about the history of human land use in key regions like the Amazon. Here, we examine the history of human occupation from a $\sim 8,500$ year-old sediment core record from Lake Caranã (LC) in the eastern Amazon. The onset of pre-Columbian activity at $L C(\sim 4,500$ cal yr B.P.) is associated with the beginning of fire management and crop cultivation, later followed by the formation of Amazonian Dark Earth soils (ADEs) 2,000 cal yr B.P. Selective forest enrichment of edible plants and low-severity fire activity altered the composition and structure of forests growing on ADEs (ADE forests) making them more drought susceptible and fire-prone. Following European colonization (1661 A.D.), the Amazon rubber boom (mid-1800s to 1920 A.D.) is associated with record-low fire activity despite drier regional climate, indicating fire exclusion. The formation of FLONA Reserve in 1974 A.D. is accompanied by the relocation of traditional populations and a fire suppression policy. Despite suppression efforts, biomass burning and fire severity in the past decade is higher than any other period in the record. This is attributed to combined climate and human factors which create optimal conditions for mega-fires in ADE forests and threatens to transform the Amazon from a net carbon sink to a net carbon source. To help mitigate the occurrence of mega-fires, a fire management policy reducing fire-use and careful fire management for farming may help to reduce fuel loads and the occurrence of mega-fires in fire-prone ADE forests. As both natural and anthropogenic pressures are projected to increase in the Amazon, this study provides valuable insights into the legacy of past human land use on modern ADE forest composition, structure, and flammability that can inform ecological benchmarks and future management efforts in the eastern Amazon.

Keywords: eastern Amazon, pre-Columbian, fire management, ADE Forests, composition, structure, mega-fires 


\section{INTRODUCTION}

\section{Contextualizing Past Human Land Use and Fire Management}

Increased temperatures driven by anthropogenic carbon emissions, earlier springs, decreased soil moisture, and drier fuels are leading to longer, more severe fire seasons in the Amazon (Malhi et al., 2002; Phillips et al., 2009; Castree, 2015; Zalasiewicz et al., 2015; Waters et al., 2016; Aragão et al., 2018). These changes have the potential to alter the composition and structure of Amazon ecosystems and increase the frequency of large-scale wildfires (>100,000 acres; henceforth "mega-fires") (Cochrane, 2009). This in turn has the potential to convert large areas of forests from net carbon sinks to net carbon sources, further impacting the global carbon cycle (Baccini et al., 2017; De Faria et al., 2017). Although modern human influence over the Earth is substantial, there is considerable debate over when human activities began to dominate the planet's natural systems. Today, the extent of anthropogenic impact is so extensive that a new geological epoch, the Anthropocene, has been proposed (Ruddiman, 2003; Smith and Zeder, 2013; Castree, 2015; Waters et al., 2016; Turney et al., 2018). Defining the Anthropocene however, is complicated by the fact that the history of human land use and fire management is poorly characterized in large parts of the world that are known to have long histories of indigenous occupation, such as the Amazon Basin (Waters et al., 2016). Past human land use and fire management has the potential to alter the composition and structure of forest ecosystems, impacting fire susceptibility and creating an enduring anthropogenic legacy in modern ecosystems (Roberts et al., 2017; Levis et al., 2018; Maezumi et al., 2018; Turney et al., 2018). To date however very little is known about the history of human land use and fire management in the Amazon. To address this issue, we implement an interdisciplinary approach integrating paleoecology, archeology, archaeobotany, and paleoclimate to assess human land use in the eastern Amazon. An 8,500-year multiproxy paleoecological reconstruction spans the history of human occupation at Lake Caranã, documenting the impact of pre-Columbian subsistence strategies and fire management and the formation of Amazonian Dark Earth soils (ADEs) on forest composition, structure, and flammability. Although the onset of agriculture or the formation of anthropogenic soils may not ultimately be the "golden spike" of the Anthropocene epoch (Certini and Scalenghe, 2011), a better understanding of the progressive intensification of past human land use and fire management practices will help to contextualize when humans began to dominate ecosystems in key regions such as the Amazon Basin.

\section{Human Impacts in the Amazon}

Humans have been present in the eastern Amazon for over 13,000 years (Roosevelt et al., 1996), although human activity remains sparse until after 4,500 cal yr B.P. (Roosevelt, 2013). Regional human activity increases after $\sim 2,000 \mathrm{cal}$ yr B.P., indicated by the formation of one of the most well-known anthropogenic soils: the pre-Columbian Amazonian Dark Earths (ADEs; traditionally called Terras Pretas do Indio) (Sombroek, 1966; Heckenberger and Neves, 2009; Gomes, 2011; Arroyo-Kalin, 2012; Eriksson et al., 2016; Iriarte, 2016, 2017). ADE formation progressively expands in the region indicated by the formation of ADEs until European conquest ( $\sim 450 \mathrm{cal}$ yr B.P.) (Heckenberger and Neves, 2009; Gomes, 2011; Arroyo-Kalin, 2012; Alves, 2016; Iriarte, 2016, 2017; Maezumi et al., 2018). Nutrient rich ADEs are abundant in charcoal and ash, along with other organic additives, including human waste, domestic refuse, crop residues, compost, and mulch, which release nutrients and carbon into the soil (Sombroek, 1966; Denevan, 1995; Kato, 1998; Lehmann et al., 2003b; Oguntunde et al., 2004; Steiner et al., 2007; Fraser et al., 2011; Eriksson et al., 2016). ADEs are indicators of preColumbian fire activity and sedentary occupation and are one of the most distinct lines of evidence of human transformation of the Amazon (Glaser and Woods, 2004; Heckenberger and Neves, 2009). Previous studies suggest frequent burning played a fundamental role in producing ADE soils (Smith, 1980; Lehmann et al., 2003a; Glaser and Woods, 2004; Woods et al., 2009; Schmidt et al., 2014; Iriarte, 2016, 2017) and improving soil fertility (Denevan, 1992, 2001; Woods et al., 2013). In addition to soil amelioration, pre-Columbians used fire for domestic activities in settlement areas for food preparation, home garden management, crop cultivation, and burning waste (Pausas and Keeley, 2009; de Souza et al., 2017). As natural fire activity is rare in old growth rainforests, high abundance of charcoal in archeological settlements is interpreted as evidence of past fire (henceforth paleofire) management in Amazon forests (Bush et al., 2016). Additionally, charcoal from lake sediments, along with the presence of crop pollen, have been interpreted as unequivocal evidence for pre-Columbian crop cultivation and fire management (Bush et al., 2000, 2007a, 2016; Whitney et al., 2012; Urrego et al., 2013; Carson et al., 2014; Maezumi et al., 2017). To date however, very little is known about the history or impact of paleofire management strategies in forests associated with ADE soils (henceforth ADE forests) in the Amazon.

\section{Modern Fire in the Amazon}

In modern Amazon forests, fire plays a transformative role in shaping forest composition (assemblage of plant species) and structure (i.e., the morphology and architecture of a plant community) (Cochrane, 2003). Changes in vegetation composition and structure can increase fire frequency (how often a fire occurs) and fire severity (amount of biomass burned) (Cochrane, 2009). Old growth rainforests (mature forests without humans but not necessarily pristine; Levis et al., 2018) cover most of the Amazon Basin (Wirth et al., 2009). These forests are non-fire adapted and fire intolerant (Cochrane et al., 1999a; Barlow and Peres, 2008). Disturbance in old growth rainforests can decrease fuel moisture (Cochrane, 2003; Palace et al., 2017) and create positive feedbacks by increasing future fire susceptibility, fuel availability, and fire intensity (Cochrane et al., 1999b). These positive feedbacks have the potential to transform large areas of old growth rainforest into scrub or savanna (Cochrane et al., 1999a). This in turn, can lower carbon storage capacity (Brienen et al., 2015) and has the potential to convert tropical rainforest from net carbon sinks to net carbon sources (Nepstad et al., 2004; Alencar et al., 2006; Phillips et al., 2009; 
Broxton et al., 2014; Baccini et al., 2017; De Faria et al., 2017; Aragão et al., 2018). Fire impacts ADE forests differently than old growth rainforests. Frequent, low-severity fire management is used to alter $\mathrm{ADE}$ forest composition and structure to increase light and reduce the number of competitors for more nutrient demanding "useful species" (e.g., edible and cultivated plants) (Junqueira et al., 2016), such as Attalea aculeatum, A. Maripa, A. speciosa, Humiria balsamifera, Mauritia flexuosa, Oenocarpus bacaba, O. Distichus, and Theobroma cacao (Fraser et al., 2011; McMichael et al., 2015; Levis et al., 2018). Fire management practices can change species composition toward higher percentages of fire adapted species through the higher sprouting ability of fire resistant seeds, selective weeding, and the reduction of non-fire adapted seed banks (Jakovac et al., 2016). Fire reduces the density of heat-intolerant seeds in the soil bank while favoring the resprouting of plants that are more heat-tolerant (Levis et al., 2018). Many plants have evolved to tolerate contact with fire, allowing them to persist in frequently burnt places (Bond and Midgley, 2001) including Sororoca (Phenakospermum guyanense), which resprouts after fire, Cumatí trees (Myrcia splendens) that form patches in gaps managed with fire (Elias et al., 2004), and Babaçu palms (A. speciosa), which persist in burned sites due to cryptogeal germination (Jackson, 1974; Levis et al., 2018). These data suggest the use of frequent low severity fire makes modern ADE forests more fire adapted than old growth rainforests (Elias et al., 2004; Levis et al., 2018). Currently, the lack of long-term paleoecology studies limits the understanding of the role paleofire management had in shaping modern $\mathrm{ADE}$ forest composition, structure, and flammability.

\section{Pre-Columbian Impacts on Forest Composition}

There is mounting evidence that pre-Columbian people had a more substantial impact on vegetation composition in modern Amazon ecosystems than previously thought (Clement et al., 2015; Levis et al., 2017; Maezumi et al., 2018). New findings show a disproportionate number of plants (accounting for half of all trees in the Amazon) are hyperdominant, and domesticated species are five times more likely to be hyperdominant than non-domesticated species (ter Steege et al., 2013; Levis et al., 2017). Ethnographic studies identify numerous land use practices that enrich the presence of useful plants on ADE soils and increase productivity (Clement et al., 2009; Levis et al., 2018) including: the removal of non-useful plants, protection of useful plants, attraction of non-human dispersers, human transportation of plants, selection of useful phenotypes, planting, soil improvement, and fire management (Levis et al., 2018). Palms (e.g., Mauritia, Attalea, Astrocaryum, Euterpe, Elaeis, and Oenocarpus) and fruit bearing trees (e.g., Agavaceae, Caryocar, Byrsonima, Theobroma cacao, and Lecythidaceae [i.e., Bertholletia excelsa]), are among some of the most enriched species, exhibiting higher concentrations on ADE soils (Clement et al., 2003; Junqueira et al., 2010; Levis et al., 2018). Additionally, numerous paleoecological studies in non-ADE forests attribute the late Holocene increase in edible palms (e.g., Mauritia) to human cultivation and fire management (Montoya et al., 2011c; Rull and Montoya, 2014).

\section{Pre-Columbian Impacts on Forest Structure}

In addition to vegetation composition, studies have also examined the structural characteristics associated with ADE forests (Woods and McCann, 1999; German, 2003; Palace et al., 2017). Surveys among modern farmers identify unique structural characteristics associated with $\mathrm{ADE}$ forests, including lower forest canopies, denser understory vegetation, and increased abundance of vines (Woods and McCann, 1999; German, 2003). A recent study indicates that in contrast to non-ADE forests, modern $\mathrm{ADE}$ forests have drier canopies and are more susceptible to drought stress (Palace et al., 2017). The disturbance associated with land use practices in $\mathrm{ADE}$ forests (e.g., burning the understory and enriching vegetation composition for edible plants) can create gaps in the vegetation canopy that increase sunlight and reduce vegetation moisture (Cochrane et al., 1999a; Aragão et al., 2018). As forest canopies become more open, incident radiation and ambient air temperatures within the canopy increase (Ray et al., 2005). The increased fuel availability and exposure to a drier and warmer microclimate, pushes ADE forest toward a fire-prone system (Aragão et al., 2018). It is possible that past human land use and paleofire management strategies had similar impacts on ADE forest structure and flammability; however, no long-term studies have examined the impact of paleofire management on vegetation structure in $\mathrm{ADE}$ forests. Additionally, very little is known about the impacts of subsequent $\mathrm{ADE}$ land use and paleofire management practices after pre-Columbian times (e.g., European rubber farming through to modern conservation efforts) (McMichael et al., 2017). As a result, the ecological impacts of human land use and paleofire management remain poorly resolved in $\mathrm{ADE}$ forests in the Amazon.

To address the long-term impacts of past human land use and fire management on $\mathrm{ADE}$ forest composition, structure, and flammability, we present a $\sim 8,500$ year high-resolution multiproxy paleoecological reconstruction from Lake Caranã (LC) in the eastern Amazon, spanning the history of permanent human occupation from the onset of pre-Columbian occupation ( $\sim 4,500$ cal yr B.P.), through the development of ADE soils $\sim 2,000$ cal yr B.P., to European colonization and subsequent rubber boom ( $\sim 300$ to 30 cal yr B.P.), and twentieth century conservation efforts, including the establishment of an ecological reserve in 1974 A.D. The addition of ${ }^{210} \mathrm{~Pb}$ dating enables the close examination of the timing of paleoecological changes following European Conquest that have hitherto been unexplored in the eastern Amazon. These data are paired with archeological and paleoclimatological records to disentangle human and climate driven ecological change. Together this interdisciplinary approach enables the investigation of the impacts of land use and paleofire management practices on composition, structure and flammability in $\mathrm{ADE}$ forest ecosystems throughout the history of human occupation in the eastern Amazon. Three potential scenarios $\left(S_{X}\right)$ of past human 
land use and fire management are examined in this study (Figure 1):

- $\left(\mathrm{S}_{1}\right)$ Humans were the dominant driver of paleofire activity.

- $\left(\mathrm{S}_{2}\right)$ Humans altered vegetation composition in ADE forests.

- $\left(\mathrm{S}_{3}\right)$ Altered vegetation composition changed forest structure increasing ADE forest flammability.

\section{METHODS}

\section{Study Area}

Lago Caranã (LC) (S 02, 50',08', W55, 02', 33", $5 \mathrm{~m}$ a.s.l.) is $\sim 0.7 \mathrm{~km}$ in diameter, $\sim 3 \mathrm{~m}$ deep, flat bottom lake located on the fluvial terrace on the eastern bank of the Rio Tapajós at the base of the Belterra Plateau in the Tapajos National Forest (FLONA), $\sim 50 \mathrm{~km}$ south of Santarém, Brazil (Figure 2). LC is located within a small closed basin and is separated from the main river channel (except during extreme flood events) by a depositional sand berm (200 m long, $\sim 3 \mathrm{~m}$ tall) located on the NE edge of the lake. Climate is seasonally dry, inter-tropical humid with a distinct wet-season between January and June. Mean annual rainfall ranges between 1,900 to $2,200 \mathrm{~mm}_{\text {year }}{ }^{-1}$ and average annual temperatures are between 21 and $31^{\circ} \mathrm{C}$ (Hijmans et al., 2005). The vegetation is composed of dense terra firme humid evergreen rainforest (Broxton et al., 2014). A $210 \mathrm{~cm}$ sediment core was collected from the SW portion of the lake using overlapping drives from a Livingston drive rod piston corer (Wright, 1967) and a modified Bolivia surface corer to collect the sediment-water interface. Cores were transported back to the University of Exeter for cold storage. LC was selected because it is located at the base of the Belterra Plateau, which is rich in archeological sites and ADE soils and today, receives limited sediment inputs from the Tapajós River, making the site ideally located to reconstruct changes in localized human land use around the Belterra Plateau.

\section{Age-Depth Model}

The age-depth model used a combination of ten ${ }^{210} \mathrm{~Pb}$ and six AMS-radiocarbon dates to develop a robust chronology for the age-depth model for LC. ${ }^{210} \mathrm{~Pb}$ dating was used to constrain the most recent paleoenvironmental changes ( $<250$ years), while AMS-radiocarbon dating was used to date sediments $>200$ years (Supplementary Methods M1). Based on the compiled geochemical, charcoal, and pollen data, three main time periods are highlighted at LC $\sim 8,500, \sim 2,500$, and $500 \mathrm{cal} \mathrm{yr}$ B.P. (Supplementary Methods M1 and Table 1). Bulk organic sediment radiocarbon ages were calibrated within Bacon using IntCal13 (Reimer et al., 2013) and modeled using Student- $t$ test distributions with wide tails to negate the need of identifying and removing potential outliers in the age-depth model (Andrés and Pérez, 2009; Blaauw and Christen, 2011). Age-depth model mean accumulation rate priors in Bacon were calculated using the ${ }^{14} \mathrm{C}$ chronology (acc.mean $=42)$ and memory priors were set slightly below default so that the model would capture accumulation rate changes driven by variable sediment delivery from the catchment (mem.strength $=2$; mem.mean $=0.4$ ).

\section{Geochemical Analyses}

The LC sediment core was scanned horizontally, end to end for magnetic susceptibility (MS) at $1 \mathrm{~cm}$ intervals using a Bartington ring sensor equipped with a $75 \mathrm{~mm}$ aperture using standard methodological procedures (Nowaczyk, 2001; Reynolds et al., 2001) (Supplementary Methods M2). X-ray fluorescence (XRF) analysis was conducted at $0.25 \mathrm{~cm}$ contiguous intervals using a portable XRF Thermo Scientific Niton 3L3t GOLDD at the University of Reading using standard methods (Supplementary Methods M3) (Croudace et al., 2006). Results were normalized using z-scores. Organic and carbonate sediment composition was determined by loss-on-ignition (LOI) conducted at $4 \mathrm{~cm}$ intervals throughout the core following standard methodology (Dean, 1974) (Supplementary Methods M4).

\section{Pollen Analysis}

Pollen was subsampled every $2 \mathrm{~cm}$ between 0 and $128 \mathrm{~cm}$ depth (0 to ca. 5,000 cal B.P.) and every $16 \mathrm{~cm}$ between 128 and $205 \mathrm{~cm}$ depth $(5,000$ to 8,500 cal B.P.), because of low pollen preservation (e.g., $<100$ terrestrial pollen grains $\mathrm{cm}^{-3}$ ) below $128 \mathrm{~cm}$. Subsampled material $\left(1 \mathrm{~cm}^{-3}\right)$ was prepared using standard digestion protocol (Faegri and Iversen, 1989), including an additional sieving stage to concentrate large cultigen pollen types such as Z. mays (Whitney et al., 2012). Large pollen grains $(>53 \mu \mathrm{m})$ concentrated through the fine-sieving methodology (Supplementary Methods M5) were scanned for maize (Zea mays) and other crop taxa producing large pollen such as manioc (Manihot esculenta), sweet potato (Ipomoea batatas), and squash (Cucurbita) (Whitney et al., 2012). Fossil pollen was identified with reference to the collection of tropical pollen specimens housed at the University of Exeter. Maize pollen grains were distinguished from those of other wild grasses according to defined morphological and size criteria (e.g., grain size: $>80 \mu \mathrm{m}$ ) (Holst et al., 2007). Pollen of Ipomoea batatas type, Manihot and Cucurbita are indistinguishable between that of cultigens and wild relatives, but we are confident that the grains we report come from cultigens since (a) wild species of these crops were absent in the botanical survey carried around the lake that represent the catchment area for these large, heavy pollen grains, (b) the co-occurrence of Ipomoea, Manihot, and Cucurbita pollen, (c) their absence at the site before the first signs of human land use, and (d) the presence of Cucurbita phytoliths in the archeological soil profiles. Therefore, we interpret it as evidence for sweet potato, manioc, and squash cultivation. Pollen taxa were grouped into edible trees, palms, and herbs, crops, other trees and herbs in the pollen diagram based on modern botanical classifications (Clement, 1999; Hanelt et al., 2001; Levis et al., 2017; Maezumi et al., 2018; Supplementary Methods M5). Pollen zones were calculated using CONISS (Grimm, 1987; Bennett, 1996) combined with a broken-stick model in $\mathrm{R}$ to determine the number of statistically significant zones (Bennett, 1996). The Euclidean distance and the Jaccard dissimilarity index (Faith et al., 1987; McCune and Grace, 2002) were calculated between consecutive fossil pollen samples to measure species composition change over time using the "vegan" package (Oksanen et al., 2017) in R. Two matrices were used to calculate dissimilarity measures: an untransformed pollen percentage matrix that 


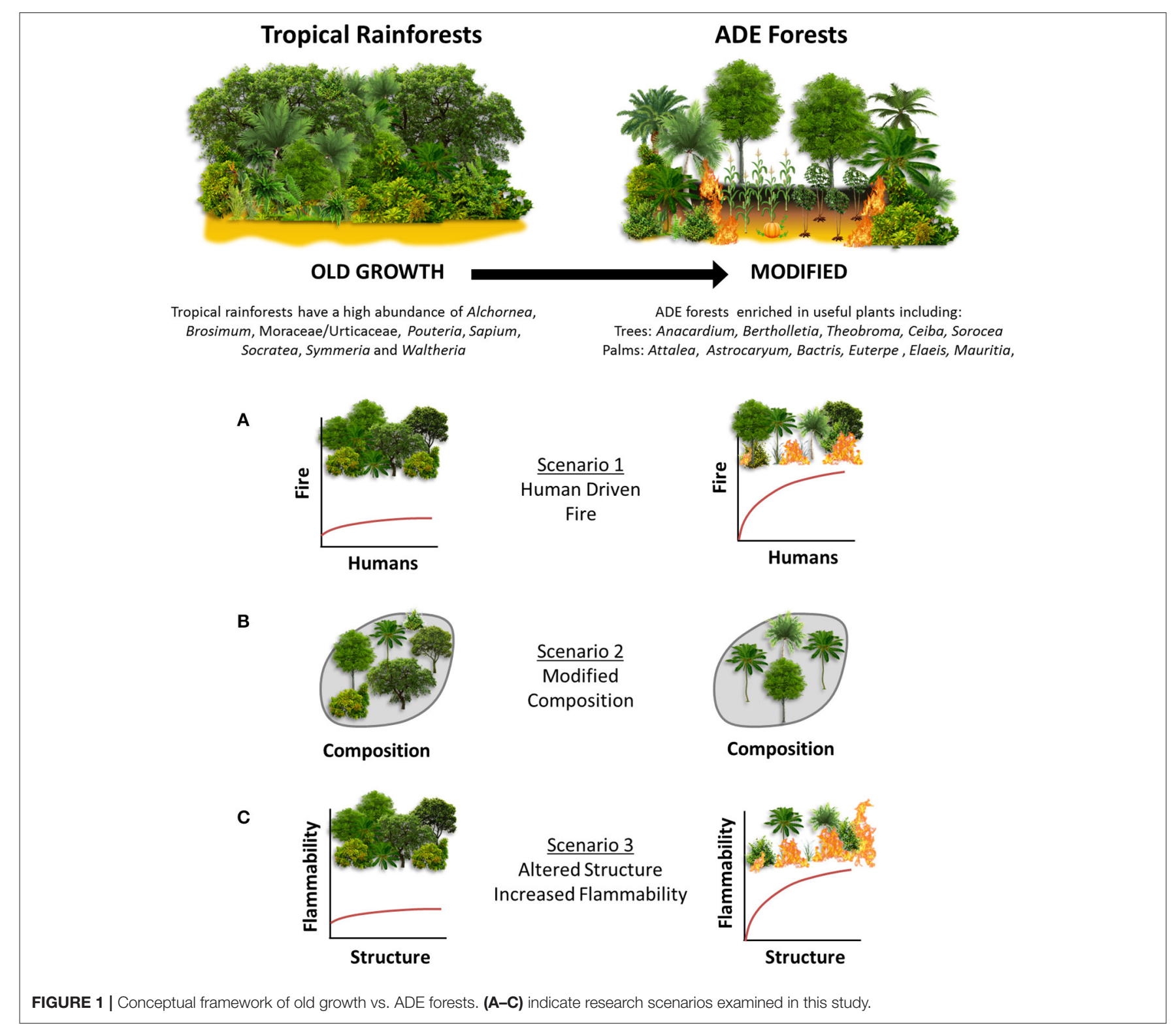

excluded crop pollen and a reduced matrix after applying an abundance and occurrence filter to reduce the potential effects of rare taxa (Supplementary Figure 1). The abundance and occurrence filter retained pollen taxa with at least $1 \%$ abundance and occurring in at least five samples (Urrego et al., 2016).

\section{Local and Regional Macrocharcoal}

The LC sediment core was subsampled for macroscopic charcoal analysis at $0.5 \mathrm{~cm}$ intervals from 0 to $210 \mathrm{~cm}$ depth using standard methods (Whitlock and Larsen, 2002; Brown and Power, 2013; Supplementary Methods M6). Charcoal influx data (particles $\mathrm{cm}^{-2} \mathrm{yr}^{-1}$ ) were used as an indicator of fire severity (the amount of biomass consumed during a fire episode or period of increased burning). Regime shift detection (RSI) was applied to determine the occurrence of statistically significant shifts in the charcoal influx data and plotted against charcoal influx data to identify changes in past fire regimes, which is interpreted here as an indicator of changes in paleofire severity (Supplementary Methods M6). CHAR statistical software was used to decompose charcoal data to identify distinct charcoal peaks using standard methodology (Higuera et al., 2007, 2009, 2010; Supplementary Methods M6). Charcoal peaks are interpreted as a fire episode (a period of increased burning). The time difference between peaks is reflected in the fire return interval (fire frequency) for every 500 years.

To examine regional biomass burning from the eastern Amazon during the Holocene, charcoal records were compiled from the Global Charcoal Database (GCD version 2.0) and analyzed using the paleofire $\mathrm{R}$ package software (version 1.1.8) (Blarquez et al., 2014). Eleven charcoal records between $3^{\circ} \mathrm{S}$ and $0.2^{\circ} \mathrm{N}$ and $43^{\circ} \mathrm{W}$ to $54^{\circ} \mathrm{W}$ that have greater than 20 charcoal samples are included in this analysis and used to 

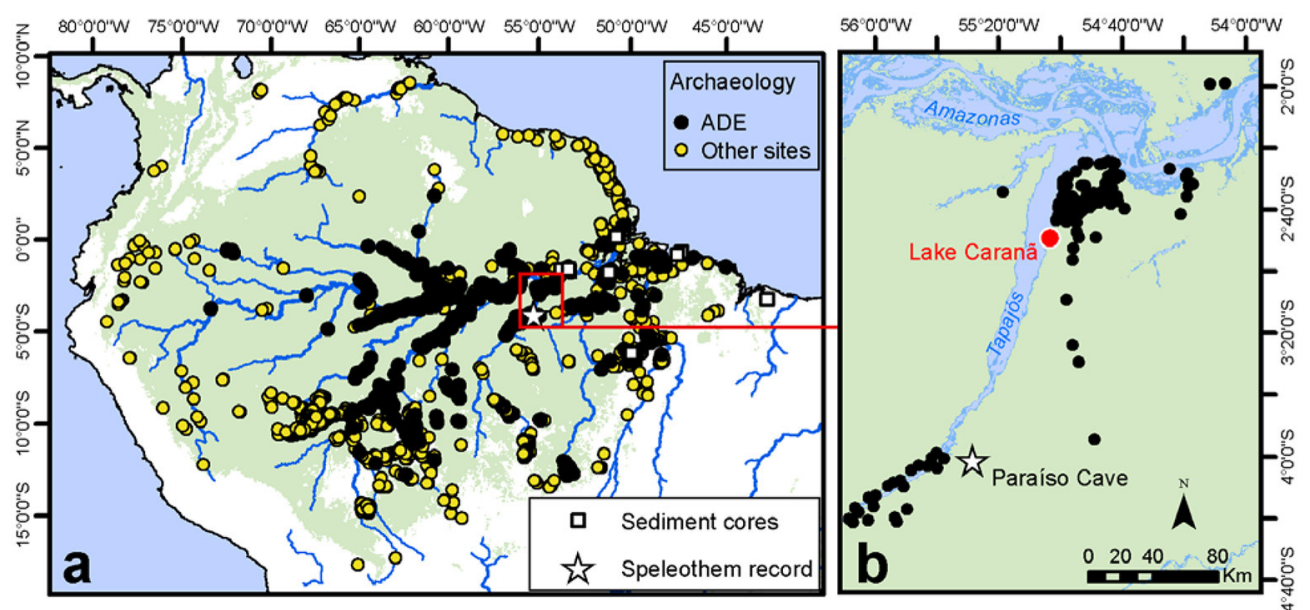

FIGURE 2 | Regional study map. (a) Distribution of ADE and other archeological sites used to calculate the SPD and site frequency values (Maezumi et al., 2018). Red box indicates inset. (b) Study area including LC red dot, star indicate Paraíso speleothem record.

TABLE 1 | Lago Caranã ${ }^{210} \mathrm{~Pb}$ and AMS radiocarbon dates.

\begin{tabular}{|c|c|c|c|c|}
\hline Method & $\begin{array}{l}\text { Depth } \\
\text { (m) }\end{array}$ & $\begin{array}{c}{ }^{210} \mathrm{~Pb}\left(\mathrm{~Bq} \mathrm{~kg}^{-1}\right) \\
\text { (supported) }\end{array}$ & $\begin{array}{c}{ }^{210} \mathrm{~Pb}\left(\mathrm{~Bq} \mathrm{~kg}^{-1}\right) \\
\text { (excess) }\end{array}$ & $\begin{array}{c}\text { Cal. Age }(2 \sigma) \\
\text { (yrs BP) }\end{array}$ \\
\hline${ }^{210} \mathrm{~Pb}$ & $0.005 \pm 0.005$ & $509.09 \pm 11.05$ & $421.93 \pm 11.61$ & $-62.9 \pm$ \\
\hline${ }^{210} \mathrm{~Pb}$ & $0.015 \pm 0.005$ & $552.61 \pm 20.50$ & $465.45 \pm 20.81$ & $-60.4 \pm$ \\
\hline${ }^{210} \mathrm{~Pb}$ & $0.025 \pm 0.005$ & $657.43 \pm 23.43$ & $570.27 \pm 23.70$ & $-57.3 \pm$ \\
\hline${ }^{210} \mathrm{~Pb}$ & $0.045 \pm 0.005$ & $610.75 \pm 21.61$ & $523.59 \pm 21.90$ & $-48.2 \pm 2.7$ \\
\hline${ }^{210} \mathrm{~Pb}$ & $0.065 \pm 0.005$ & $709.05 \pm 26.33$ & $621.88 \pm 26.57$ & $-36.5 \pm 4.8$ \\
\hline${ }^{210} \mathrm{~Pb}$ & $0.085 \pm 0.005$ & $384.40 \pm 14.81$ & $297.24 \pm 15.23$ & $-21.5 \pm 7.2$ \\
\hline${ }^{210} \mathrm{~Pb}$ & $0.105 \pm 0.005$ & $295.22 \pm 12.41$ & $208.06 \pm 12.91$ & $-13.1 \pm 8.9$ \\
\hline${ }^{210} \mathrm{~Pb}$ & $0.125 \pm 0.005$ & $163.75 \pm 7.11$ & $76.59 \pm 7.95$ & $-6.0 \pm 10.9$ \\
\hline${ }^{210} \mathrm{~Pb}$ & $0.145 \pm 0.005$ & $394.06 \pm 16.48$ & $306.90 \pm 16.86$ & $5.6 \pm 15.4$ \\
\hline \multirow[t]{2}{*}{${ }^{210} \mathrm{~Pb}$} & $0.165 \pm 0.005$ & $196.66 \pm 7.83$ & $109.50 \pm 8.60$ & $42.2 \pm 45.2$ \\
\hline & & Lab code & ${ }^{14} \mathrm{C}$ yrs BP & \\
\hline${ }^{14} \mathrm{C}$ & $0.30 \pm 0.005$ & Beta-469035 & $1030 \pm 30$ & $941 \pm 107$ \\
\hline${ }^{14} \mathrm{C}$ & $0.60 \pm 0.005$ & Beta-469036 & $1130 \pm 30$ & $1067 \pm 105$ \\
\hline${ }^{14} \mathrm{C}$ & $0.80 \pm 0.005$ & Beta-469037 & $2350 \pm 30$ & $2394 \pm 68$ \\
\hline${ }^{14} \mathrm{C}$ & $0.100 \pm 0.005$ & Beta-469038 & $1830 \pm 30$ & $1752 \pm 113$ \\
\hline${ }^{14} \mathrm{C}$ & $0.115 \pm 0.005$ & Beta-427240 & $4340 \pm 30$ & $4936 \pm 91$ \\
\hline${ }^{14} \mathrm{C}$ & $0.205 \pm 0.005$ & Beta-424296 & $7700 \pm 40$ & $8492 \pm 83$ \\
\hline
\end{tabular}

create a Regional Charcoal Curve (RCC; Table 2). To facilitate inter-site comparison, the 11 records are pretreated using standard protocol for transforming and standardizing individual records, which includes: (1) transforming non-influx data (e.g., concentration particles $\mathrm{cm}^{-3}$ ) to influx values (particle $\mathrm{cm}^{-2} \mathrm{yr}^{-1}$ ), (2) homogenizing the variance using the BoxCox transformation, (3) rescaling the values using a minimax transformation to allow comparisons among sites, and (4) rescaling the values to $\mathrm{z}$-scores using a base period of 200 years (Marlon et al., 2008; Power et al., 2008). Sites are smoothed with a 400 year half width smoothing window and a bootstrap of 100 years (Blarquez et al., 2014).

\section{SPD and Site Frequencies}

We compiled all available radiocarbon dates from archeological sites in the lower Tapajós in order to assess potential changes in the temporal distribution of human settlements and periods of population growth or decline. We used the Sum of the calibrated Probability Distributions (SPDs) as a method for representing chronological trends in radiocarbon datasets (Supplementary Methods M7). SPDs are produced by calibrating each independent date in the sample and adding the results to produce a single density distribution. This has the advantage of including the full range of probabilities associated with calibrated dates, instead of using single point estimates (Shennan et al., 2013; Timpson et al., 2014; Downey et al., 2016; Goldberg et al., 2016; Zahid et al., 2016). Provided there is an adequate sample size and measures of chronometric hygiene are employed, SPDs can be a reliable method to assess past population dynamics, even if in relative terms. In addition to the SPD, a histogram of the number of occupied sites is used as another proxy of human activity, based on the medians of the calibrated dates per 100 year intervals. We assume that intervals with higher probability densities and/or higher frequency of sites occupied simultaneously correspond to periods when pre-Columbian populations were larger.

\section{RESULTS}

\section{Core Lithology and Chronology}

The total length of the core recovered from LC was $210 \mathrm{~cm}$ with a basal ${ }^{14} \mathrm{C}$ age of $\sim 8,500 \mathrm{cal}$ yr B.P. (Figure 3 ). The stratigraphy shows no signs of slumping or perturbation. The lithology is dominated by white sandy clay $(185-210 \mathrm{~cm})$, which shifts to gray sandy clay $\sim 160 \mathrm{~cm}$. From 160 to $140 \mathrm{~cm}$ the sediments are characterized by very dusky red silt that changes to reddish 
TABLE 2 | Existing charcoal records used for regional charcoal curve (RCC) from the eastern Amazon compiled from the Global Charcoal Database.

\begin{tabular}{|c|c|c|c|c|c|}
\hline Site & Latitude & Longitude & Samples & Vegetation & Citation \\
\hline $\begin{array}{l}\text { Lake } \\
\text { Tapera }\end{array}$ & 0.13004 & -51.077726 & 36 & TEF & $\begin{array}{l}\text { De Toledo and } \\
\text { Bush, } 2007\end{array}$ \\
\hline $\begin{array}{l}\text { Lake } \\
\text { Marcio }\end{array}$ & 0.163768 & -51.06244 & 38 & TEF & $\begin{array}{l}\text { De Toledo and } \\
\text { Bush, } 2007\end{array}$ \\
\hline Comprida & -1.624914 & -53.99962 & 23 & TEF & Bush et al., 2000 \\
\hline Geral & -1.646903 & -53.59553 & 70 & TEF & Bush et al., 2000 \\
\hline $\begin{array}{l}\text { Lago } \\
\text { Crispim }\end{array}$ & -0.622637 & -47.64363 & 41 & TEF & $\begin{array}{l}\text { Behling and } \\
\text { Lima da Costa, } \\
2001\end{array}$ \\
\hline $\begin{array}{l}\text { Rio } \\
\text { Curua }\end{array}$ & -1.734653 & -51.45492 & 36 & TEF & $\begin{array}{l}\text { Behling and da } \\
\text { Costa, } 2000\end{array}$ \\
\hline $\begin{array}{l}\text { Lagoa } \\
\text { do Caçó }\end{array}$ & -2.970219 & -43.26781 & 79 & TEF & $\begin{array}{l}\text { Ledru et al., } \\
2002\end{array}$ \\
\hline $\begin{array}{l}\text { Lagoa da } \\
\text { Curuca }\end{array}$ & -0.766667 & -47.85 & 25 & TEF & Behling, 2001 \\
\hline Saracuri & -1.678846 & -53.57028 & 86 & TEF & $\begin{array}{l}\text { Bush et al., } \\
2007 a\end{array}$ \\
\hline $\begin{array}{l}\text { Santa } \\
\text { Maria }\end{array}$ & -1.578308 & -53.60537 & 89 & TEF & $\begin{array}{l}\text { Bush et al., } \\
2007 a\end{array}$ \\
\hline Carajas & -6 & -50.16052 & 45 & TEF & Cordeiro, 2004 \\
\hline
\end{tabular}

gray medium-grained sand between 140 and $120 \mathrm{~cm}$. A band of dark red brown organics is present from 120 to $115 \mathrm{~cm}$, which transitions to very dark brown detrital peat to the surface of the core. The ten ${ }^{210} \mathrm{~Pb}$ dates and six ${ }^{14} \mathrm{AMS}$ dates were broadly consistent. The use of Bacon and Bayesian statistics to reconstruct the accumulation history at LC allowed the inclusion of every radiocarbon date that was taken throughout the LC core and develops robust estimations of age-depth uncertainty. The distribution of profile iterations identified radiocarbon ages Beta-469035 and Beta-469038 as potential outliers. Rather than omit these data points, they were retained and contributed to the uncertainty distribution of the model (Supplementary Methods M1), but the reversals are not sufficient to warrant the exclusion from the Bacon-derived chronology. The sedimentation rate from $\sim 8,500$ years to $\sim 1,000 \mathrm{cal}$ yr B.P. is slow $\left(\sim 0.2 \mathrm{~mm} \mathrm{yr}^{-1}\right)$. Sedimentation increased $\left(\sim 0.4 \mathrm{~mm} \mathrm{yr}^{-1}\right)$ around 1,000 to $40 \mathrm{cal}$ yr B.P. The sedimentation rate increased progressively to the highest values in the record ( 0.8 to $\left.2.5 \mathrm{~mm} \mathrm{yr}^{-1}\right)$ during the last century.

\section{Geochemistry, LOI, and Bulk Density}

From $\sim 8,500$ to $\sim 4,500 \mathrm{cal}$ yr B.P. LC is characterized by the highest levels of $\mathrm{Ti}, \mathrm{Fe}$, and $\mathrm{K}$, coupled with record high MS and bulk density values (Figure 4). Ca levels were below the level of detection, thus ratios for $\mathrm{Ti} / \mathrm{Ca}$ and F/Ca could not be calculated. Together, these data suggest a period of increased riverine influence. After $\sim 4,500 \mathrm{cal}$ yr B.P., the decrease in Fe, Ti, $\mathrm{K}$, bulk density, and MS are synchronous with the increase in LOI values indicating increased bulk sediment organic content. These data are interpreted as a shift to lacustrine conditions signaling the formation of the lake. After $\sim 1,250$ cal yr B.P., bulk density remains low and increases in $\mathrm{K}, \mathrm{MS}$ and LOI values indicate increased nutrients and organic matter that are associated with the apex pre-Columbian activity in the region.

\section{Fossil Pollen}

Prior to $\sim 8,500$ to $4,500(210-115 \mathrm{~cm})$ Pollen Accumulation Rate (PAR) is low ( $<100$ grains per $\mathrm{cm}^{3}$; Figure 3 ) thus, is presented as presence data in the pollen diagram (Supplementary Figure 2). Following the formation of LC $\sim 4,500$ cal yr B.P., PAR increases and is presented as percentage data in the pollen diagrams (Figure 5 and Supplementary Figure 2). After $\sim 4,500$ cal yr B.P., the dissimilarity distances show the same trend when using the complete and the filtered pollen percentage matrices (Supplementary Figures 1, 2). Euclidean distance shows an abrupt change in species composition at $\sim 2,500 \mathrm{cal}$ yr B.P. equivalent to a $75 \%$ composition dissimilarity indicated by the Jaccard index (Figure 5). Both dissimilarity indices fluctuated between $\sim 1,200$ and $500 \mathrm{cal}$ yr B.P. coincident with a shift in the fire regime. The Jaccard index shows ca. 55\% dissimilarity around $500 \mathrm{cal}$ yr B.P., with composition dissimilarity values gradually decreasing toward the present reaching a minimum of $42 \%$ dissimilarity when the charcoal influx and number of archeological sites were also at a minimum. Percentage dissimilarity reached record high values ca. $70 \%$ in the most modern pollen assemblage. Following the increase in PAR after the formation of LC $\sim 4,500$ cal yr B.P., 4 pollen zones are identified in the pollen record:

Pollen Zone 1: $\sim 4,500-2,500$ cal yr B.P.; 115-82 cm; Zone 1 is characterized by ca. 40 to $50 \%$ edible plants and $\sim 60$ to $70 \%$ other trees, palms, and herbs (Figure 6). Vegetation composition is dominated by $\sim 30 \%$ Mauritia/Mauritiella, $\sim 20 \%$ Moraceae/Urticaceae. Combretaceae/ Melastomataceae, Solanaceae, Ilex, Cyperaceae, and Cassia are each $\sim 10 \%$. Maize is present continuously after ca. $4,300 \mathrm{cal}$ yr B.P. and sweet potato (Ipomea sp.) is present at ca. 3,200 cal yr B.P.. Neurospora spores are present between 2,000 and 1,500 cal yr B.P. indicating local fires and a potential shift in the nutrient inputs of the lake.

Pollen Zone 2: 2,500-1,250 cal yr B.P.; 82-61 cm; Zone 2 is marked by a decrease in PAR that is not associated with a change in sediment accumulation rate (Figure 3), suggesting a decline in the amount of pollen producing vegetation on the landscape. There is an increase in edible trees and palms ( $\sim 60$ to $70 \%$ ) at the expense of other trees, palms, and herbs. Mauritia/Mauritiella pollen increases ca. $20 \%$, while Moraceae/Urticaceae and Combretaceae/ Melastomataceae decrease $\sim 5$ to $10 \%$. Manioc (Manihot sp.) is present ca. 2,250 cal yr B.P. along with the continued presence of maize. Mougeotia spores are present indicating warm, shallow, stagnant, oxygen-rich conditions.

Pollen Zone 3: 1,250-500 cal yr B.P.; 61-30 cm; Zone 3 continues to be dominated by edible trees and palms $(\sim 70$ $80 \%$ ). Mauritia/Mauritiella ( $\sim 40 \%$ ) pollen is accompanied by increases in Apiaceae, Byrsonima, and Bignoniaceae ( $~ 5 \%)$. Moraceae/Urticaceae is $\sim 10 \%$. Maize and manioc pollen are present along with squash ca. $600 \mathrm{cal}$ yr B.P. Gelasinospora 


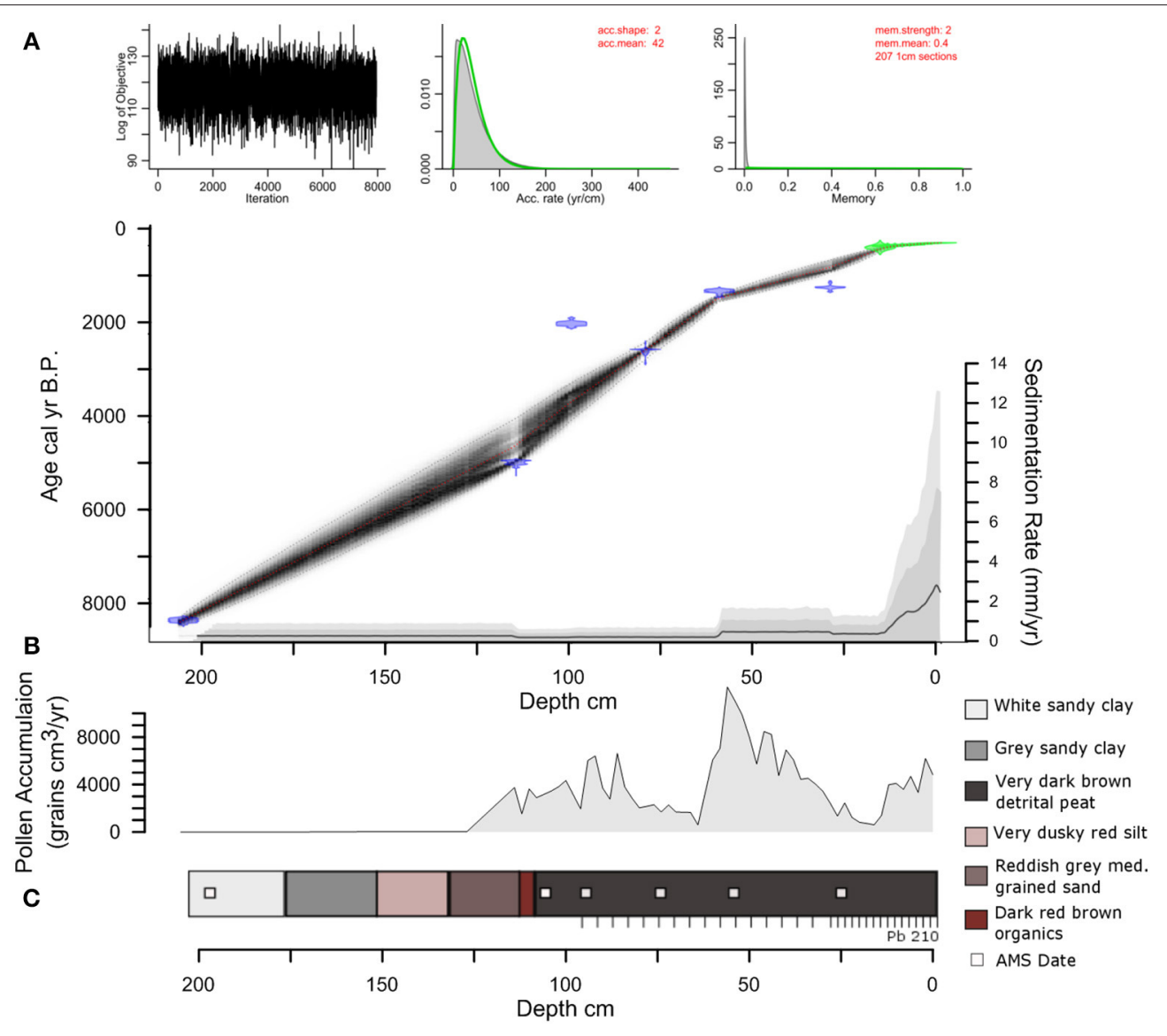

FIGURE 3 | Lago Caranã core lithology and Age model. (A) Age-depth model with MCMC iterations (top left) and priors (green curves) and posteriors (gray histograms) for accumulation rate (top middle) and memory (top right). The age model iterations (black hatching) are based on radiocarbon ages (blue pdfs) and ${ }^{210} \mathrm{~Pb}$ ages (green pdfs), with model mean (red dashed) and $2 \sigma$ (black dashed) distributions. (B) Pollen Accumulation Rates from sediment core. (C) Sediment core lithology. AMS dates indicated by the white squares, ${ }^{210} \mathrm{~Pb}$ indicated by tick marks. Low PAR prior to $\sim 4,700$ cal yr B.P. is attributed to a combination of sandy sediments and low organics that likely reduced pollen preservation.

spores are present indicating dry, oligotrophic conditions, and are often associated with the occurrence of charcoal.

Pollen Zone 4: 500 cal yr B.P. to present; 30-0 cm; Zone 4 exhibits a decline in PAR that is attributed to the increase in sedimentation rates (Figure 3). There is a decrease in edible trees and palms ( $\sim 70$ to $45 \%)$ pollen ca. 250 cal yr B.P. driven by declines in Mauritia/Mauritiella ( $10 \%)$, Apiaceae, Bignoniaceae ( $\sim 5 \%)$, Byrsonima $(\sim 10 \%)$, and Pouteria and Solanum $(\sim 5 \%)$. Moraceae/Urticaceae pollen increases from $\sim 10$ to $30 \%$. Maize, manioc, and squash are present in Zone 4. However, there is an absence of crop pollen between 300 to 150 cal yr B.P. synchronous with a decline in edible trees and palms $(\sim 30 \%)$ coupled with an increase of other trees, palms, and herbs $(\sim 30 \%)$. Dracontium, a common medicinal plant, increases during this period indicating increased disturbance and drier conditions. The continued presences of Gelasinospora spores indicate dry, oligotrophic conditions and abundance of charcoal. The presence of Mougeotia spores indicates oxygen-rich freshwater conditions. PAR increases again after $\sim 30 \mathrm{cal} \mathrm{yr} \mathrm{B.P.} \mathrm{and}$ is associated with an increase in sediment accumulation rates.

\section{Local and Regional Macrocharcoal}

Local charcoal influx data from LC is low prior to $\sim 4,500 \mathrm{cal}$ yr B.P. and is attributed to the increased riverine influence during this period that corresponds to the wettest period in the last $\sim 8,500$ years (Figure 6). There is an increase in influx values between $\sim 4,500$ and 1,250 cal yr frequency B.P. (Figures 7, 8), synchronous with the presence of maize and sweet potato crop pollen. Fire and peak magnitude values indicate frequent low severity fire activity during this period. Influx values increase between $\sim 1,250$ and 500 cal yr B.P. associated with maximum pre-Columbian activity in the region (Figure 7). Three peak magnitude episodes are associated with the apex of pre-Columbian activity, the largest of which is synchronous with the presence of maize and squash cultivation and the formation of ADEs on the Belterra Plateau $\sim 520$ cal yr B.P. (Maezumi et al., 2018; Supplementary Figure 3, Supplementary Table 1). Following decreased charcoal influx values between $\sim 500$ to 


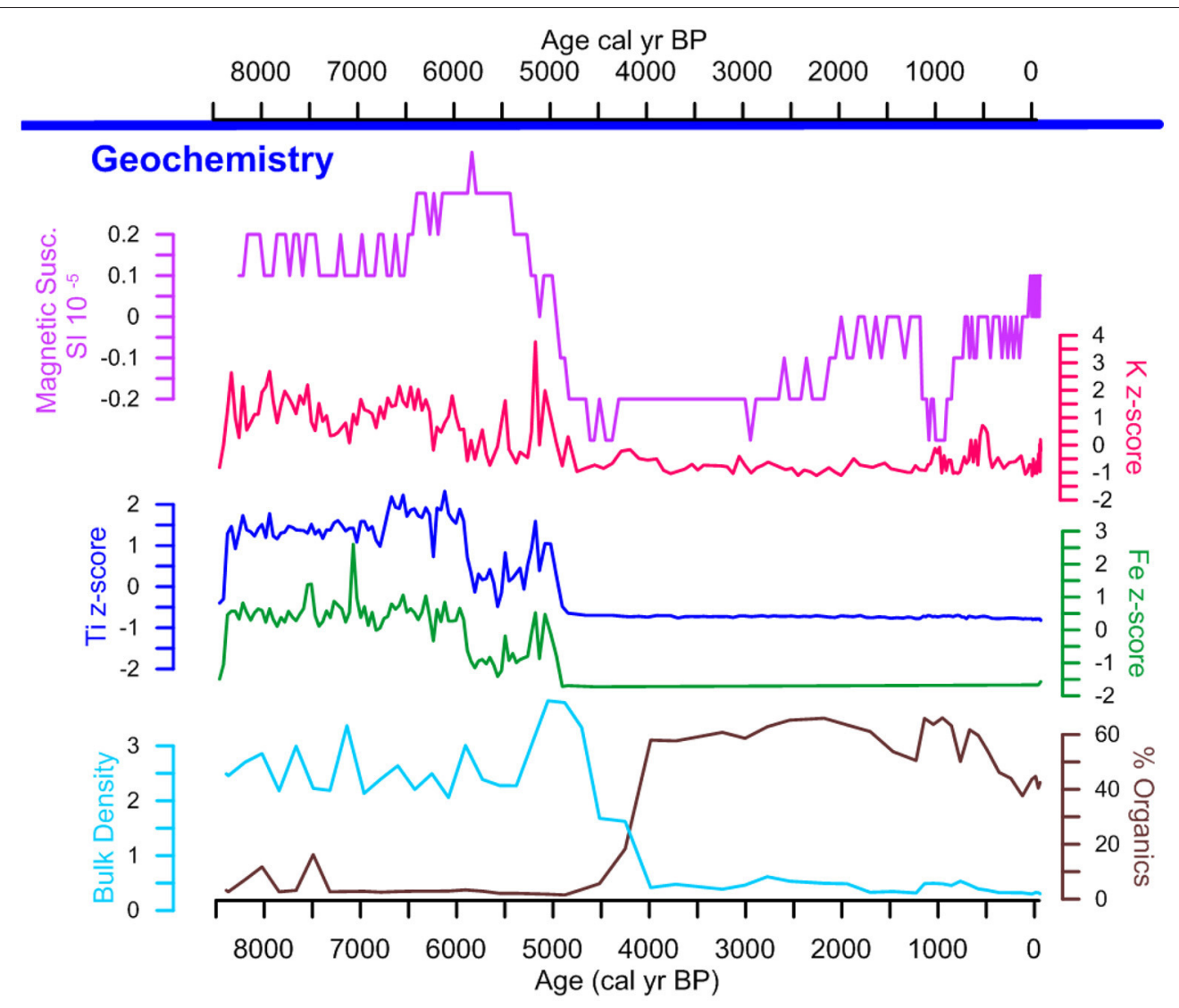

FIGURE 4 | Lago Caranã geochemistry. Geochemical proxies including magnetic susceptibility in purple, XRF z-scores for K in pink, Ti in blue, Fe in green, bulk density in teal and total organics in brown.

100 cal yr B.P., influx values progressively increase during the last century with record high influx and peak magnitude values occurring in the past decade (Figure 8). RCC values from the 11 egional records (Table 2) follow a similar pattern of biomass burning to LC. There is an initial increase in RCC values $\sim 8,000$ cal yr B.P. synchronous with SPD and site frequency values (Figure 6). RCC values indicate a gradual increase in regional biomass burning between 6,500 and $1,500 \mathrm{cal}$ yr B.P., followed by a progressive decrease toward present. The decline in regional biomass burning is asynchronous with increasing dry conditions indicated from the Paraíso speleothem record (Figure 6).

\section{SPD and Site Frequencies}

SPD values exhibit a brief increase to 0.2 at $\sim 8,000 \mathrm{cal} \mathrm{yr}$ B.P., followed by an absence of AMS dated sites until $\sim 4,500$ cal yr B.P. Between $\sim 4,500$ and 1,250 cal yr B.P., SPD values range between 0.1 and 0.2 . Site frequency values are between 1 and 2 (Figure 6). SPD values increase to ca. $0.4 \sim 1,250 \mathrm{cal}$ yr B.P. and site frequency values are between 1 and 5. SPD values reach highest record values $\sim 500 \mathrm{cal} \mathrm{yr}$ B.P. of 0.9 coupled with frequency values of 4 to 5 , associated with the apex of pre-Columbian activity in the region. After $\sim 500 \mathrm{cal}$ yr B.P. SPD and frequency values decrease to between 0.1 to 0 coupled with decreasing site frequency values of 1 to 0 associated with European contact (1542 A.D.) and colonization (1661 A.D.) (Figures 7,8).

\section{DISCUSSION}

This research implements an interdisciplinary approach to examine the history of human land use and fire management in the eastern Amazon during the Holocene. Charcoal and pollen analysis indicate the onset of fire activity and crop cultivation around the lake begins $\sim 4,500$ cal yr B.P. After $\sim 2,500 \mathrm{cal}$ yr B.P. pollen analysis demonstrates pre-Columbian people altered vegetation composition in ADE forests through the enrichment of edible forest species at the expense of other trees, palms, and herbs. The selective removal of other trees, palms, and herbs, combined with the use of frequent burning, likely altered forest structure by increasing canopy gaps, decreasing fuel moisture, and increasing forest flammability. Increased burning combined with a more open canopy likely played a pivotal role in the later development of ADE soils $\sim 2,000$ cal yr B.P. Together these data indicate the legacy of human land use altered the composition and structure of ADE forests making them more fire prone compared to old growth rainforests. 


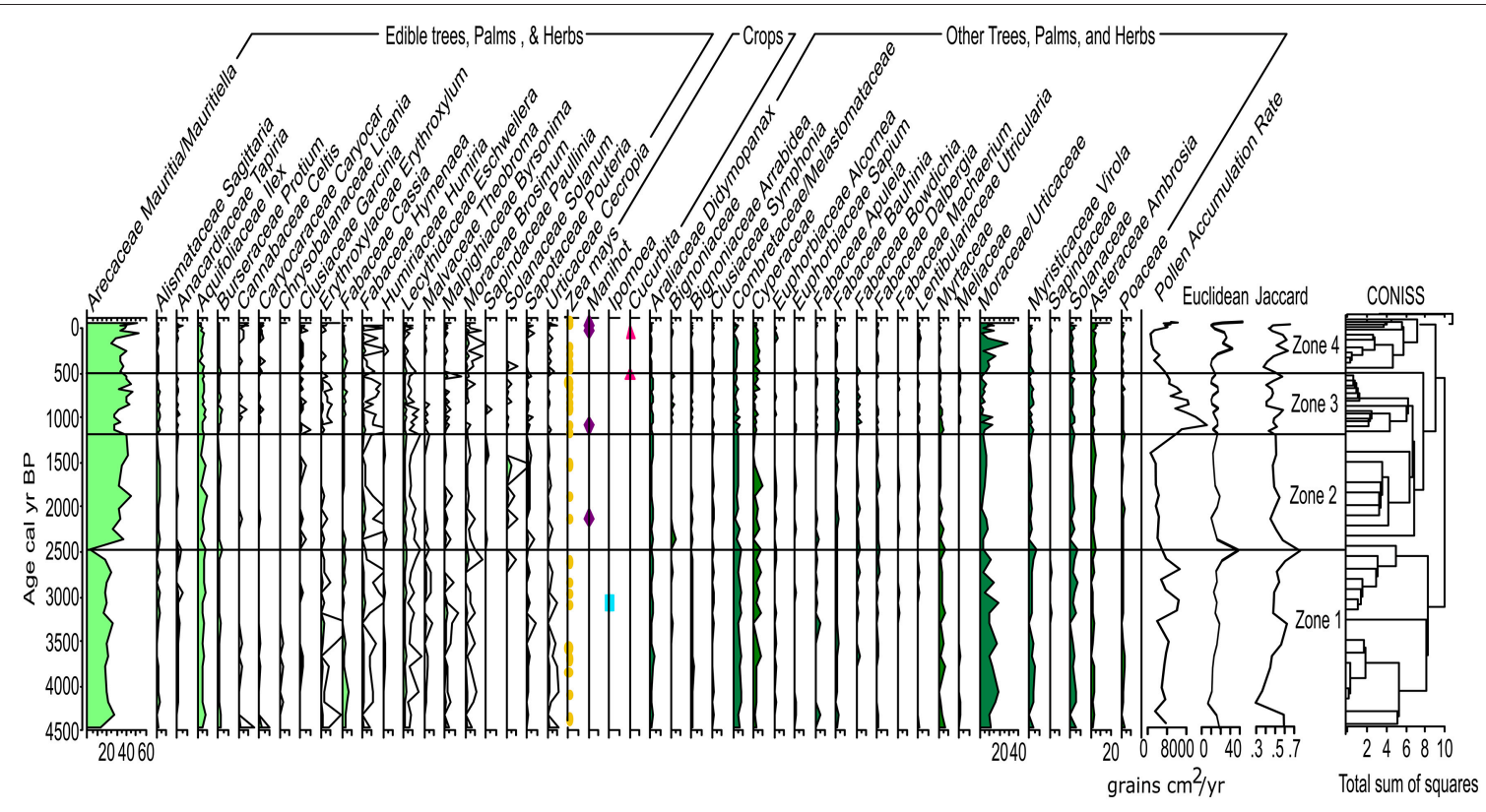

FIGURE 5 | Lake Caranã pollen data. Percentage pollen diagram (silhouettes show 10X exaggeration curves); Pollen Zones determined from CONISS. Light green represents edible plants, dark green represents other trees, palms and herbs, symbols represent total counts of crop pollen: yellow circle maize (Zea mays), blue square sweet potato (Ipomoea), purple diamond manioc (Manihot), pink triangle squash (Cucurbita). PAR, Euclidean, and Jaccard metrics data on the far right of the graph.

\section{Pre-Columbian Fire Management in the Eastern Amazon}

Charcoal data indicate frequent, low severity fires increase around LC after $\sim 4,500 \mathrm{cal} \mathrm{yr} \mathrm{BP.} \mathrm{There} \mathrm{is} \mathrm{a} \mathrm{similar} \mathrm{increase}$ in regional biomass burning indicated by the RCC composite curve (Figure 6). This increase in local and regional fire activity began during the wettest period in the past $\sim 45,000$ years (Wang et al., 2017). Pollen data indicate vegetation was dominated by moist, fire-adverse, fire-intolerant vegetation (Figure 5). Drought conditions are a key factor in increased forest flammability in modern Amazon vegetation (Brando et al., 2014; Aragão et al., 2018) thus, natural wildfire is expected to be low during wetter than average periods (Bush et al., 2007b). Thus, the anomalously wet conditions associated with the onset in increased biomass burning $\sim 4,500 \mathrm{cal}$ yr B.P. suggest climate was not the dominant driver of increased paleofire activity. The increase in biomass burning is synchronous with the intensification of human activity indicated by increased SPD and site frequency values (Figure 6), and the presence of maize $(\sim 4,300 \mathrm{cal}$ yr B.P.) and sweet potato $(\sim 3,100$ cal yr B.P.) crop pollen (Figures 6,7$)$. The synchronous onset of fire with increased human activity in the region, combined with crop cultivation at LC, during the wettest period in the Holocene, supports $S_{1}$ : human activity opposed to climate, was the dominant driver of local and regional scale biomass burning in the eastern Amazon during this time. Furthermore, following European contact ( $\sim 400 \mathrm{cal}$ yr B.P.) and later colonization ( $\sim 300 \mathrm{cal}$ yr B.P.), declines in local charcoal and RCC values occur despite the driest climate conditions in the past $\sim 8,500$ years, and are synchronous with declines in pre-Columbian populations indicated by the SPD and site frequency values (Figure 8). These data further support the interpretation that human paleofire management vs. regional climate was the dominant driver of local and regional scale fire activity in the eastern Amazon.

Local fire activity increases between $\sim 1,250$ and $400 \mathrm{cal}$ yr B.P., during the Late pre-Columbian Tapajó Period (LPTP) $(\sim 1,000$ to $400 \mathrm{cal}$ yr B.P.) (Stenborg et al., 2012), represented by the increase in SPD and site frequency values (Figure 7). At this time, the Santarém polity comprised an area of $\sim 23,000$ $\mathrm{km}^{2}$ with sites extending for hundreds of miles along river bluffs and interior plateaus (Roosevelt, 1999). Sites during this period extended for hundreds of miles along river bluffs and interior plateaus. The largest occupation, located in the modern city of Santarém, is estimated to contain 500 ha of ADE soils, of which 16 ha constitute the core of the pre-Columbian settlement (Nimuendajú, 1948, 2004; Roosevelt, 1999; Gomes, 2001, 2017; Stenborg et al., 2012). The increase in fire activity during this period occurs prior to the shift to drier regional climate conditions, suggesting pre-Columbian fire management continued to be the dominant driver of fire activity at LC. The continued presence of rainforest taxa $(\sim 35$ to $>40 \%)$ (Burn et al., 2010), despite the progressive increase in pre-Columbian activity in the region indicates large-scale deforestation did not occur around the lake. This interpretation is supported by the synchronous declines in MS values, indicating reduced erosion, which would be expected to increase in a large-scale land clearance scenario (Barlow and Peres, 2008). This interpretation is supported from phytolith data from neighboring ADE soil 


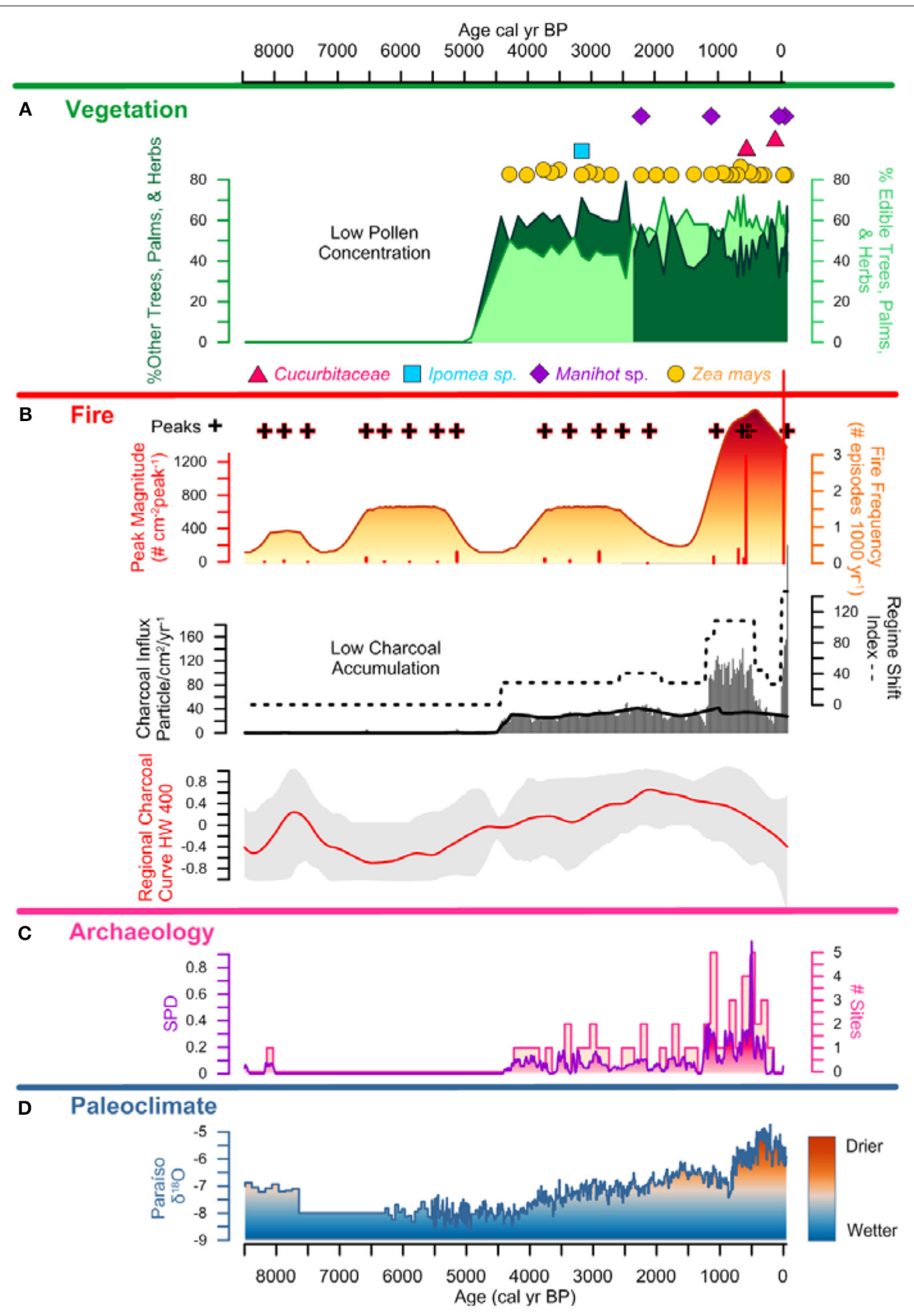

FIGURE 6 | Lago Caranã Summary Figure 8,500 cal yr BP to Present: (A) vegetation: pollen summary data of edible and other trees, palms, and herbs, and crop pollen including maize (Z. mays), sweet potato (Ipomea sp.), manioc (Manihot sp.), and squash (Cucurbita), (B) fire: charcoal influx with black line indicating background, RSI, fire frequency, peaks, and peak magnitude from CHAR Analysis, and regional charcoal curve from sites compiled from the GCD, (C) archeology: summary data calculated from the sum of calibrated probability distributions (SPDs) and site frequency data (Maezumi et al., 2018), (D) paleoclimate: data from Paraíso Cave (Wang et al., 2017).

profiles (Supplemental Figure 3) that indicate the continued presence of closed canopy forest (Maezumi et al., 2018). Together, these data suggest low severity fire management strategies were used within the rainforest to increase soil nutrient availability and clear understory vegetation, which reduced the build-up of fuel loads. Clearing the understory vegetation would have decreased 

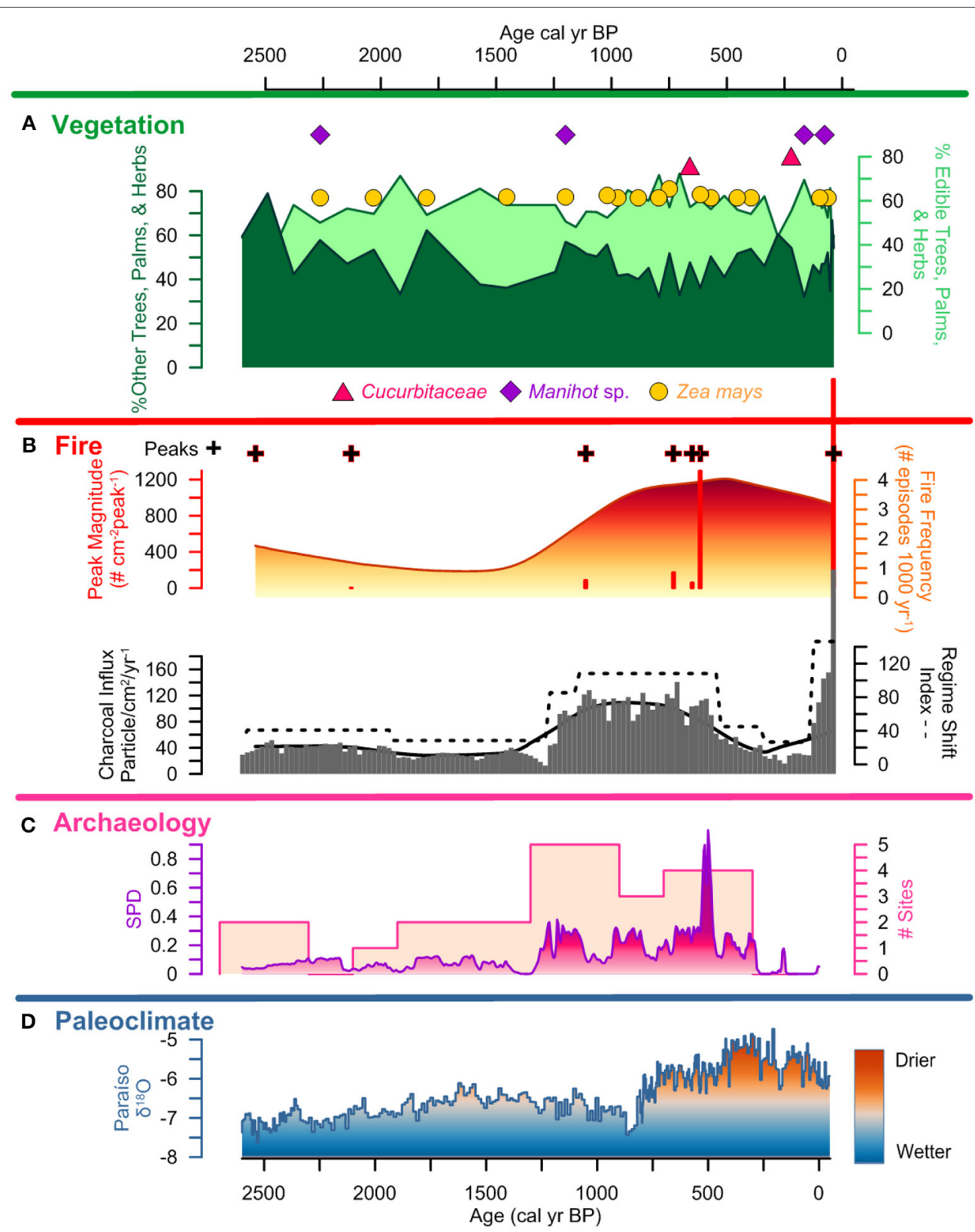

FIGURE 7 | Lago Caranã summary figure 2,500 cal yr BP to present: (A) vegetation: pollen summary data of edible and other trees, palms, and herbs, and crop pollen including maize (Z. mays), sweet potato (Ipomea sp.), manioc (Manihot sp.), and squash (Cucurbita), (B) fire: charcoal influx with black line indicating background, RSI, fire frequency, peaks, and peak magnitude from CHAR Analysis, and regional charcoal curve from sites compiled from the GCD, (C) archeology: summary data calculated from the sum of calibrated probability distributions (SPDs) and site frequency data (Maezumi et al., 2018), (D) paleoclimate: data from Paraíso Cave (Wang et al., 2017).

the risk of escaped wildfires that could damage edible forest trees, cultivated areas, and soils used for crop cultivation. Similar practices have been observed by modern farmers in ethnographic studies (Welch et al., 2013; Levis et al., 2018).

Fire activity remained low during European colonization ( 2300 to $30 \mathrm{cal}$ yr B.P.) despite increased European settlement associated with the Amazon rubber exploitation (Weinstein, 1983; Schroth et al., 2003). Modern rubber tappers identify fire as the primary threat to rubber groves (Schroth et al., 2003). Rubber tappers of Mestizo and indigenous ancestry were forcibly removed from their traditional livelihoods and forced to work the rubber plantations (McMichael et al., 2017). The record low levels of fire activity during the rubber boom, despite regional climate being drier than present, suggests an abandonment of traditional pre-Columbian fire management practices. Rubber tappers were likely excluding fire from the forests to protect 


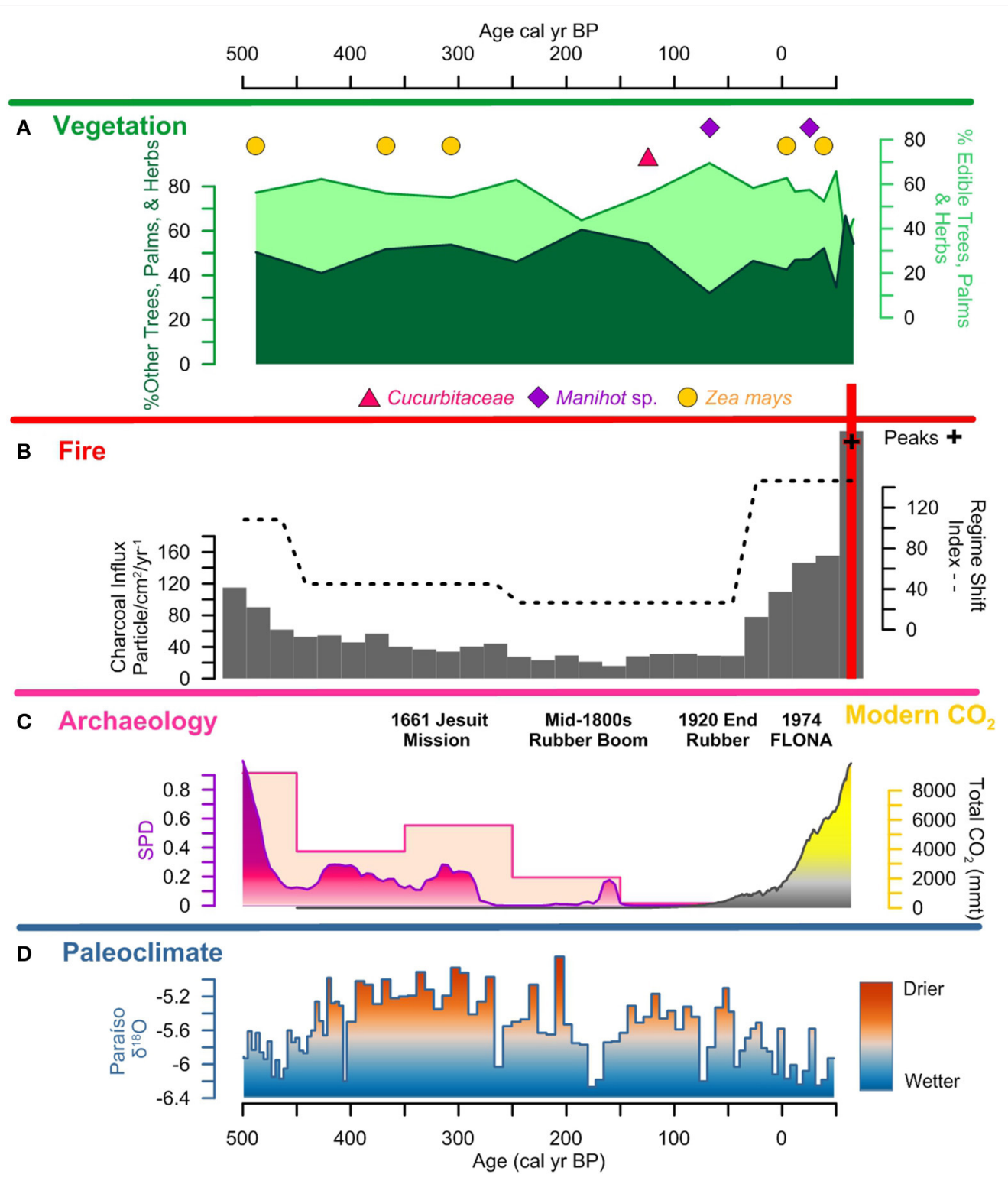

FIGURE 8 | Lago Caranã summary figure 500 cal yr BP to present: (A) vegetation: pollen summary data of edible and other trees, palms, and herbs, and crop pollen including maize (Z. mays), sweet potato (Ipomea sp.), manioc (Manihot sp.), and squash (Cucurbita), (B) fire: charcoal influx with black line indicating background, RSI, fire frequency, peaks, and peak magnitude from CHAR Analysis, and regional charcoal curve from sites compiled from the GCD, (C) archeology: summary data calculated from the sum of calibrated probability distributions (SPDs) and site frequency data (Maezumi et al., 2018), modern $\mathrm{CO}_{2}$ concentrations in yellow from (Marland et al., 2008) (D) paleoclimate: data from Paraíso Cave (Wang et al., 2017).

the valuable, fire intolerant rubber plantations (Figure 8). These data suggest a fire suppression strategy may have been in place in the LC watershed from the early 1800s (Weinstein, 1983). The end of the rubber boom ( $\sim 30$ cal yr B.P.) is followed by a progressive increase in biomass burning and fire severity during the last century (Figure 8). Biomass burning reaches record levels in the past decade despite an active fire suppression policy within the FLONA Reserve (Cordeiro, 2004). The recent increase in biomass burning is attributed to the compounding factors of forest disturbance, fire management for farming, and the increase in the length and severity of the dry season, driven by anthropogenic climate change, which have created optimal conditions for large, frequent wildfires in the eastern Amazon (Nepstad et al., 2004; Marengo et al., 2008, 2011; Le Page et al., 2017; Aragão et al., 2018).

\section{Pre-Columbian Impact on Forest Composition}

Modern vegetation surveys suggest pre-Columbian people have had a lasting legacy on modern forest composition by enhancing portions of useful (Levis et al., 2012; Lins et al., 2015) and/or 
edible forest taxa (Maezumi et al., 2018). Our data suggest preColumbian land management practices (e.g., enriching forests with edible plants) may account for the modern hyperdominance of useful plants in Amazon forests (Junqueira et al., 2011; ter Steege et al., 2013; Clement et al., 2015; Almeida et al., in review). Around $\sim 2,500$ cal yr B.P. the increase in edible plants at LC is driven primarily by Mauritia/Mauritiella, along with Agavaceae, Caryocar, Byrsonima, Lecythidaceae, and Theobroma among others (Figure 6). The increase in Mauritia/Mauritiella follows a similar pattern to sites across seasonally flooded savannas in lowland South America during this period (Kahn and de Granville, 1992; Behling and Hooghiemstra, 1998, 1999, 2000; Burbridge et al., 2004; Montoya and Rull, 2011; Montoya et al., 2011b; Balee, 2013; Rull et al., 2013; Rull and Montoya, 2014; Maezumi et al., 2015; Junqueira et al., 2017). This regional phenomenon has been attributed to both natural and anthropogenic drivers (Montoya and Rull, 2011; Montoya et al., 2011a,c; Rull and Montoya, 2014; Maezumi et al., 2015). Disentangling climate and pre-Columbian drivers of the late Holocene expansion of Mauritia/Mauritiella and other useful plants is complicated by the synchroneity of changes in regional climate (Baker et al., 2001b; Cruz et al., 2009; Novello et al., 2012; Wang et al., 2017) and the apex of pre-Columbian activity in lowland Amazon during this time (Roosevelt, 1999; Schaan, 2010, 2012; Gomes, 2011; Schaan et al., 2012; Stenborg et al., 2012). Paleoclimate records indicate an anti-phasing in regional precipitation patterns between the eastern Amazon and other areas of lowland South America (Baker et al., 2001b; Cruz et al., 2009; Novello et al., 2012; Wang et al., 2017). As many regions transition toward wetter conditions in the late Holocene (Baker et al., 2001a), the eastern Amazon exhibits the driest Holocene conditions after $\sim 2,000$ cal yr B.P. (Wang et al., 2017). $M$. flexuosa is dependent on local hydrology (e.g., water table depth) (Kahn, 1987), favoring soils that remain flooded during the dry season (Kahn and de Granville, 1992; Huber, 1995a,b). Thus, areas that experienced wetter regional climates during the late Holocene likely favored the expansion of M. flexuosa (Rull, 1992; Montoya et al., 2011b; Rull and Montoya, 2014). The shift toward drier climate conditions in the eastern Amazon (Wang et al., 2017) would have been less conducive to the expansion of M. flexuosa (Rull, 1992), suggesting an alternative mechanism drove the abrupt increase in Mauritia/Mauritiella and other edible plant taxa at $\mathrm{LC} \sim 2,500 \mathrm{cal}$ yr B.P..

Archeological studies based on seed records from the Colombian Amazon indicate naturally occurring edible plants, including $M$. flexuosa, were exploited by hunter-gatherer cultures since the early Holocene (Morcote Ríos et al., 1998; MorcoteRíos and Bernal, 2001). Palms remain the most important group of plants for traditional populations throughout Amazonia (Anderson and Anderson, 1977; Balick, 1988; Kahn and de Granville, 1992; Campos and Ehringhaus, 2009). SPDs and site frequency data indicate a progressive increase in preColumbian activity in the eastern Amazon after 4,500 cal yr B.P. (Figure 6), followed by the increase in edible plants $\sim 2,500 \mathrm{cal}$ yr B.P. that is associated with increased Euclidean dissimilarity distance and the Jaccard dissimilarity index values (Figures 5, 7). Enriching the ecology of the landscape and the demography of edible plant populations would have made more productive and favorable landscapes for pre-Columbians (Clement et al., 2009). Pre-Columbians likely encouraged the propagation of Mauritia/Mauritiella along with other edible plants (Figures 68), while removing other trees, palms, and herbs from the understory vegetation through burning and weeding of the understory (Levis et al., 2018). This interpretation is supported by the presence of charcoal at LC and evidence of polycrop cultivation at LC and on local ADE soils, combined with lack of key disturbance indicators, including Cecropia and herbaceous species such as Poaceae and Asteraceae (Maezumi et al., 2018; Supplementary Figure 2). Together these data support $\mathbf{S}_{\mathbf{2}}$, that pre-Columbian people were altering forest composition in $\mathrm{ADE}$ forests around LC.

Edible plant values exhibit a $\sim 20 \%$ decline (Figure 8) coupled with increased variability in the Euclidean dissimilarity distance and the Jaccard dissimilarity index values during European colonization and subsequent rubber boom (mid-1800s to $\sim 1920$ A.D.; $\sim 150$ to $100 \mathrm{cal}$ yr B.P.). This likely reflects an abandonment of traditional pre-Columbian land use practices as people of Mestizo and indigenous ancestry were forced to work the rubber plantations (McMichael et al., 2017). Additionally, the absence of crop pollen and record low charcoal levels during this period suggest that crop cultivation was either abandoned around the LC shore or, if not abandoned, was being practiced differently prior to the time of European colonization. It is important to note that while the presence of rubber plantations are well-documented in the region during the rubber boom (Weinstein, 1983; Schroth et al., 2003), and numerous modern rubber plantations are present on the Belterra Plateau $\sim 5 \mathrm{~km}$ from LC (Schroth et al., 2003), there is an absence of Hevea brasiliensis pollen in the $\mathrm{LC}$ record. This absence is attributed to a limited dispersal range of $H$. brasiliensis $(\sim 0.3$ to $1.1 \mathrm{~km})$ (Yeang and Chevallier, 1999). Despite the absence of rubber pollen preserved at $\mathrm{LC}$, the change in human land use during the rubber boom is reflected in the increase in other trees and palm taxa. Following the end of the rubber boom $(\sim 100 \mathrm{cal} \mathrm{yr}$ B.P.) there is a $\sim 20 \%$ increase in edible plant values coupled with the presence of maize, squash, and manioc crop pollen (Figure 8), suggesting a return to land-use practices similar to the pre-Columbian period. Following the establishment of FLONA Reserve in 1974 and the relocation of local inhabitants out of the area (MacDonald, 2010), there is an increase in other trees, palms, and herbs and disturbance indicators (e.g., Cecropia and Dracontium), coupled with the highest level of Ambrosia in the record. The relocation of people from the area would have resulted in a decline in weeding and understory clearance. The increase in disturbance indicators is attributed to the early stages of forest succession that has been characterized by a higher percentage of soil coverage by new weeds, higher weed species richness, and a higher relative proportion of annual and leguminous plants in modern vegetation studies (Major et al., 2005). Despite recent declines in edible plants, the enriched levels have not returned to pre-human occupation levels at LC or in modern vegetation surveys of $\mathrm{ADE}$ and non-ADE forest plots in the surrounding area (Maezumi et al., 2018; Almeida et al., in review). Additionally, enriched levels of palms and 
other useful plants have been documented in modern forests growing on pre-Columbian mounds, anthropogenic soils, and geoglyphs abandoned more than 400 years ago in other parts of the Amazon, suggesting the persistent legacy of pre-Columbian enrichment, irrespective of modern land use histories (Erickson and Balée, 2006; Walker, 2011; Quintero-Vallejo et al., 2015; Watling et al., 2017). These data indicate pre-Columbian vs. later periods of human land use was the primary driver of ADE forest enrichment. These data suggest the process of pre-Columbian forest enrichment combining the propagation of edible plants and removal of other trees, palms, and weeds through clearing the understory with low level fire activity and weeding (Levis et al., 2018) has had a lasting legacy on the composition of ADE forests.

\section{Pre-Columbian Management and Altered ADE Forest Structure}

Changes in the modern structural characteristics of ADE forests, including canopy moisture and drought susceptibility (Palace et al., 2017), are attributed to forest disturbance caused by management practices to enrich ADE forest composition and improve soils for cultivation (Glaser and Woods, 2004; Levis et al., 2018). The enrichment of forest composition alters the structure of ADE forests by thinning the canopy through the removal of weeds and other trees and palms, increasing light penetration by opening gaps in the canopy through clearing of understory with fire (Levis et al., 2018). In comparison with old growth forests, disturbed $\mathrm{ADE}$ forests are characterized by greater canopy opening, larger stocks of dead material, drier, warmer microclimate, and lower wood density species (Baker et al., 2004), making them more susceptible to mortality during droughts (Phillips et al., 2009; Palace et al., 2017). As a result, disturbed ADE forests are more flammable and exhibit increased fire intensity (Cochrane, 2009; Alencar et al., 2015). Modern observations indicate that these structural changes can be observed in $\mathrm{ADE}$ forests that have no documented land use following European conquest, as well as in forests that have experienced continued exploitation following colonization (Lins et al., 2015; Quintero-Vallejo et al., 2015; Junqueira et al., 2017; Palace et al., 2017). These data suggest the structural characteristics associated with ADE forests are attributed to preColumbian, opposed to later human land use and that these structural changes persist in modern ADE forests. The alteration in forest structure likely began during the pre-Columbian period with the onset of low-severity fire management and polycrop cultivation $\sim 4,500 \mathrm{cal}$ yr B.P. and intensified $\sim 2,500$ cal yr B.P. as pre-Columbian forest and fire management strategies intensified to enrich forest composition, remove other trees and palms, and clear the understory for ADE soil formation and crop cultivation. The increased nutrient availability associated with ADE soils would have increased crop yields and provided more fertile soils for the intensification of polyculture (mixed cropping) agroforestry. These processes of forest and fire management would have increased canopy openings and decreased fuel moisture and ambient forest temperatures, making ADE forests more flammable and fire prone. Similarities in the structure of ADE forests, despite recent land use histories, support $\mathbf{S}_{3}$ : the persistent legacy of $\sim 4,500$ years of pre-Columbian forest enrichment and fire management altered ADE forest structure, making them more susceptible to drought induced fire activity compared to old growth rainforests.

\section{Implications for Modern Fire Management in ADE Forests}

Hotter, drier climates coupled with longer dry seasons are creating the "perfect storm" of factors driving increased fire activity in the Amazon. The link between drought severity, fuel availability, and fire activity has created optimal conditions for mega-fires in the eastern Amazon (Aragão et al., 2018). As the eastern Amazon exhibits some of the highest densities of ADE sites in the Amazon (Sombroek, 1966; Woods and McCann, 1999; Nimuendajú, 2004; Schaan, 2012; Stenborg et al., 2012), the abundance of more fire-prone ADE forests, coupled with the projected increase in the length and severity of the dry season driven by increasing ENSO activity (Cochrane et al., 1999a; Alencar et al., 2006, 2015; Soares-Filho et al., 2012), make the eastern Amazon extremely vulnerable to drought induced fire activity. During pre-Columbian times, periodic, low-severity fires were likely used to clear out much of the forest understory fuels for crop cultivation, leaving edible trees unaffected, while also reducing the risk of high-severity fires. Following the preColumbian period fire management was largely excluded from the landscape, likely from the abandonment of traditional fire management practices and to protect fire-adverse rubber groves. Despite fire suppression efforts following the establishment of FLONA in 1974 (De Andrade and De Carvalho, 2011), fire severity has progressively increased, reaching record levels of annual fire activity in the past 15 years (Figures 8, 9). The shift from $\sim 4,000$ years of low-severity pre-Columbian fire management to a fire suppression policy, which continues to characterize modern management policy, has likely resulted in a build-up of understory fuels in ADE forests (Figure 9). Increased fuel loads in drier, fire-prone $\mathrm{ADE}$ forests can increase fire severity and the likelihood of stand replacing events as well as increased soil damage and erosion, and the likelihood of fire leakage into non-fire adapted, fire-intolerant old grown rainforests (Cochrane, 2009). Furthermore, reducing the accidental spread of fires in the Amazon has broader implications for the global carbon budget. Fire is the main pathway for removing plant biomass and transferring the stored carbon in tropical vegetation to the atmosphere (Gatti et al., 2014). Carbon emissions from the Brazilian Amazon are increasingly driven by drought induced forest fires (Aragão et al., 2018). The combined effects of increased droughts and increased forest fires is reducing carbon stocks, threatening to convert Amazon forests from net carbon sinks to net carbon sources, further contributing to global carbon emissions (Nepstad et al., 2004; Alencar et al., 2006; Phillips et al., 2009; Broxton et al., 2014; Baccini et al., 2017; De Faria et al., 2017; Aragão et al., 2018). Although the compounding factors of warmer temperatures, drier fuels, and longer fire seasons threaten to impact all ecosystems in the Amazon, fire-prone ADE forests will likely be more susceptible 

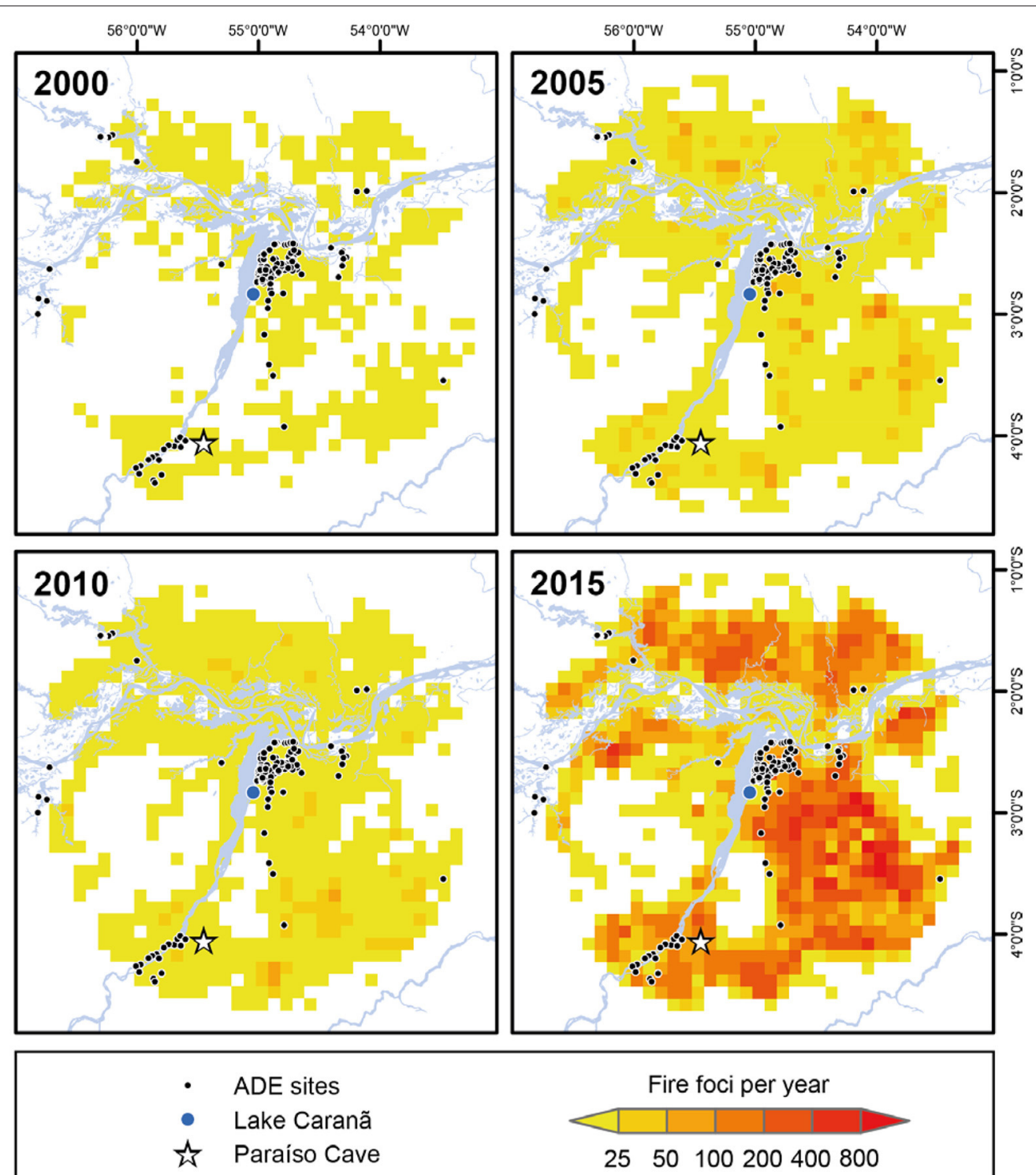

FIGURE 9 | The progressive increase in fire activity in the eastern Amazon from 2000 to 2015 . The total number of fire foci per 0.1 square decimal degree at 5-year intervals between 2000 and 2015 within a 100-km radius around Lake Caranã. Data on fire activity for the period 1999-2017 were obtained from the online database of the Brazilian National Institute of Spatial Research (INPE) (http://www.inpe.br/queimadas/portal). The raw data represent fire foci at least 30 m² detected on satellite imagery of varying resolutions.

to drought induced fire activity and may act as ignition nexuses that increase the spread and severity of fires and increase carbon emissions.

Today ADE soils are no longer being created on a broad scale (Neves et al., 2003), fire management in existing ADE soils continue to be widely used by modern societies to cultivate crops and enable the diversification and intensification of food production in the Amazon (Woods et al., 2013; Junqueira et al., 2016). Implementing ADE fire management strategies during the off-peak fire season (e.g., wet season; January to April) targeting the reduction of fire-use and more careful fire management for farming ADE soils (Aragão et al., 2018) may help to reduce fuel loads and the likelihood of high severity, stand replacing fire events and escaped fires into old growth rainforests (Bowman et al., 2009). Studies have previously demonstrated that reducing fuel loads decreases fire severity and lowers the accidental spread of fires into neighboring forests (Brando et al., 2014) and improves the effectiveness of fire suppression efforts in subsequent fire seasons (Cochrane and Ryan, 2009; Brando et al., 2014). The use of an off-peak, fire-reduction management policy may help to reduce the risk and spread of mega-fires from ADE forests, while improving sustainable ADE forest strategies by local farmers that may ultimately contribute to long-term conservation efforts in the eastern Amazon. 

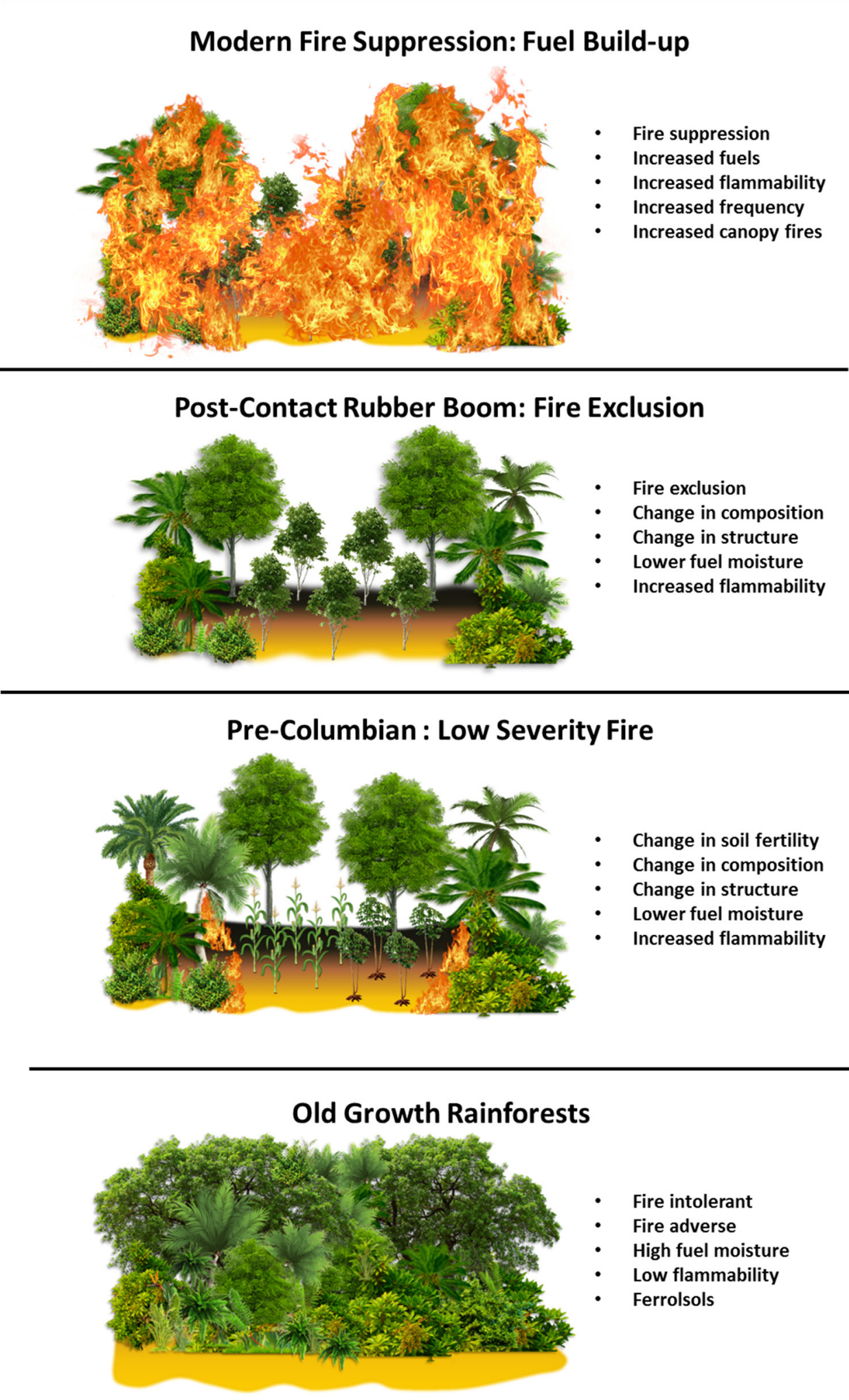

FIGURE 10 | A conceptual figure of phases of the history of human land use and fire management in the eastern Amazon. 


\section{CONCLUSIONS AND INSIGHTS FOR THE ANTHROPOCENE}

As the chronological benchmarks of the Anthropocene continue to be refined, a better understanding of the history and legacy of human occupation in areas such as the Amazon are needed. Here, a $\sim 8,500$ year multiproxy paleoecological reconstruction spans the history of human occupation at LC in the eastern Amazon, beginning with the arrival of pre-Columbian people $\sim 4,500$ cal yr B.P., followed by the formation of ADE soils $\sim 2,000$ cal yr B.P., and continues with European colonization and subsequent rubber boom $\sim 300$ to $30 \mathrm{cal}$ yr B.P., modern human occupation in the past century, and the establishment of FLONA reserve in 1974 A.D. There is a progressive intensification of pre-Columbian ecosystem impacts in the eastern Amazon that begins $\sim 4,500 \mathrm{cal}$ yr B.P. with the onset of fire management and polyculture around LC (Figure 10). Charcoal data from LC indicate pre-Columbian fire management, characterized by low severity fires, was the dominant driver of local and regional scale fire activity during pre-Columbian times. Pollen data indicate the enrichment of edible plant species $\sim 2,500 \mathrm{cal}$ yr B.P., which persists in modern ADE forest composition. The process of enriching forest composition likely altered forest structure through thinning the canopy and clearing understory vegetation with fire, which would have decreased fuel moisture and increased drought susceptibility. These changes in the structural characteristics made ADE forests more fireprone and more susceptible to drought induced fire activity. Modern ADE forests continue to exhibit unique compositional and structural characteristics when compared to old growth rainforests, even in $\mathrm{ADE}$ forests that have been abandoned since pre-Columbian times, suggesting the persistent legacy of pre-Columbian land and fire management. Fire suppression in the twentieth century has likely resulted in the build-up of understory fuels as the result of secondary succession in $\mathrm{ADE}$ forests. The high concentration of fire-prone ADE forests in the eastern Amazon, coupled with the projected increase in the frequency and severity of droughts and longer fire seasons related to warming temperatures, have created optimal conditions for mega-fires in the eastern Amazon. These megafires threaten to convert Amazon forests from net carbon sinks to a net carbon sources. Implementing fire management policies targeting the reduction of fire-use and more careful fire

\section{REFERENCES}

Alencar, A. A., Brando, P. M., Asner, G. P., and Putz, F. E. (2015). Landscape fragmentation, severe drought, and the new Amazon forest fire regime. Ecol. Appl. 25, 1493-1505. doi: 10.1890/14-1528.1

Alencar, A., Nepstad, D., and Diaz, M. C. V. (2006). Forest understory fire in the Brazilian Amazon in ENSO and Non-ENSO years: area burned and committed carbon emissions. Earth Interact. 10, 1-17. doi: 10.1175/EI150.1

Alves, D. T. (2016). Plant food consumption and the origin of amazonian dark earth in the lower tapajós region. Beyond Waters, 61.

Anderson, A. B., and Anderson, A. B. (1977). Os nomes e usos de palmeiras entre uma tribo de índios Yanomama. Acta Amaz. 7, 5-13. doi: 10.1590/1809-43921977071005 management for farming in $\mathrm{ADE}$ forests may help to reduce fuel loads and fire severity and decrease the risk and spread of fires into fire-intolerant old growth rainforests. This may aid in the reduction of fire related carbon emissions, and ultimately improve long-term forest conservation efforts in the eastern Amazon. As chronological benchmarks of the Anthropocene continue to be resolved, this study is an example of an integrative, interdisciplinary approach to examine the persistent legacy of human land use and fire management on the composition, structure, and flammability of modern ecosystems in the eastern Amazon.

\section{DATA AVAILABILITY}

The source data used to support the findings of this study have been made publically available through Neotoma and the Latin American Pollen Database.

\section{AUTHOR CONTRIBUTIONS}

JI, SM, and DS designed the research. SM, DA, and JI carried out archeological and paleoecological fieldwork. SM carried out pollen, charcoal, geochemistry and magnetic susceptibility analyses. DA carried out phytolith analysis. SM and JI led the writing of the paper with inputs from all other authors.

\section{ACKNOWLEDGMENTS}

Funding for this research was supported by the PAST (PreColumbian Amazon-Scale Transformations) European Research Council Consolidator Grant to JI (ERC_Cog 616179). Research was conducted under permit 01506.004836/2014-69 from the Instituto do Patrimônio Histórico e Artístico Nacional (IPHAN) and ICMBio permit 106/14-FNT. We thank all residents of Maguarí and Jamaraquá community for their hospitality and help.

\section{SUPPLEMENTARY MATERIAL}

The Supplementary Material for this article can be found online at: https://www.frontiersin.org/articles/10.3389/fevo. 2018.00111/full\#supplementary-material 
on aboveground measurements of gain and loss. Science. 358, 230-234. doi: $10.1126 /$ science.aam5962

Baker, P. A., Rigsby, C. A., Seltzer, G. O., Fritz, S. C., Lowenstein, T. K., Bacher, N. P., et al. (2001a). Tropical climate changes at millennial and orbital timescales on the Bolivian Altiplano. Nature 409, 698-701. doi: 10.1038/35055524

Baker, P. A., Seltzer, G. O., Fritz, S. C., Dunbar, R. B., Grove, M. J., Tapia, P. M., et al. (2001b). The history of South American tropical precipitation for the past 25,000 years. Science 291, 640-643. doi: 10.1126/science.291.5504.640

Baker, T. R., Phillips, O. L., Malhi, Y., Almeida, S., Arroyo, L., Di Fiore, A., et al. (2004). Increasing biomass in Amazonian forest plots. Philos. Trans. R. Soc. Lond. Ser. B Biol. Sci. 359, 353-365. doi: 10.1098/rstb.2003.1422

Balee, W. (2013). Cultural Forests of the Amazon. A Historical Ecology of People and Their Landscapes. Tuscaloosa, AL: University of Alabama Press.

Balick, M. J. (1988). "Palms and development in the humid tropics Volume. VI", in Anais do $1^{\circ}$ Simpósio do Trópico Úmido (Belém), 121-140.

Barlow, J., and Peres, C. A. (2008). Fire-mediated dieback and compositional cascade in an Amazonian forest. Philos. Trans. R. Soc. Lond. B. Biol. Sci. 363, 1787-1794. doi: 10.1098/rstb.2007.0013

Behling, H. (2001). Late Quaternary environmental changes in the Lagoa da Curuca region (eastern Amazonia, Brazil) and evidence of Podocarpus in the Amazon lowland. Veg. Hist. Archaeobot. 10, 175-183. doi: 10.1007/PL00006929

Behling, H., and da Costa, M. L. (2000). Holocene environmental changes from the Rio Curuá record in the Caxiuanã region, eastern Amazon basin. Quat. Res. 53, 369-377. doi: 10.1006/qres.1999.2117

Behling, H., and Hooghiemstra, H. (1998). Late quaternary palaeoecology and palaeoclimatology from pollen records of the savannas of the Llanos Orientales in Colombia. Palaeogeogr. Palaeoclimatol. Palaeoecol. 139, 251-267. doi: 10.1016/S0031-0182(97)00139-9

Behling, H., and Hooghiemstra, H. (1999). Environmental history of the Colombian savannas of the Llanos Orientales since the last glacial maximum from lake records El Pinal and Carimagua. J. Paleolimnol. 21, 461-476. doi: 10.1023/A:1008051720473

Behling, H., and Hooghiemstra, H. (2000). Holocene Amazon rainforest-savanna dynamics and climatic implications: high-resolution pollen record from Laguna Loma Linda in eastern Colombia. J. Quat. Sci. 15, 687-695. doi: 10. 1002/1099-1417(200010)15:7<687::AID-JQS551>3.0.CO;2-6

Behling, H., and Lima da Costa, M. (2001). Holocene vegetational and coastal environmental changes from the Lago Crispim record in northeastern Pará State, eastern Amazonia. Rev. Palaeobot. Palynol. 114, 145-155. doi: 10.1016/S0034-6667(01)00044-6

Bennett, K. D. (1996). Determination of the number of zones in a biostratigraphical sequence. New Phytol. 132, 155-170. doi: 10.1111/j.1469-8137.1996.tb0 4521.x

Blaauw, M., and Christen, J. A. (2011). Flexible palaeoclimate age-depth models using an autoregresive gamma process. Bayesian Anal. 6, 457-474. doi: 10.1214/11-BA618

Blarquez, O., Vannière, B., Marlon, J. R., Daniau, A.-L., Power, M. J., Brewer, S., et al. (2014). Paleofire: an R package to analyse sedimentary charcoal records from the global charcoal database to reconstruct past biomass burning. Comput. Geosci. 72, 255-261. doi: 10.1016/j.cageo.2014.07.020

Bond, W. J., and Midgley, J. J. (2001). Ecology of sprouting in woody plants: the persistence niche. Trends Ecol. Evol. 16, 45-51. doi: 10.1016/S0169-5347(00)02033-4

Bowman, D. M., Balch, J. K., Artaxo, P., Bond, W. J., Carlson, J. M., and Cochrane, M. A, et al. (2009). Fire in the earth system. Science 324, 481-484. doi: $10.1126 /$ science. 1163886

Brando, P. M., Balch, J. K., Nepstad, D. C., Morton, D. C., Putz, F. E., Coe, M. T., et al. (2014). Abrupt increases in Amazonian tree mortality due to drought-fire interactions. Proc. Natl. Acad. Sci. U.S.A 111, 6347-6352. doi: 10.1073/pnas.1305499111

Brienen, R. J., Phillips, O. L., Feldpausch, T. R., Gloor, E., Baker, T. R., Lloyd, J., et al. (2015). Long-term decline of the Amazon carbon sink. Nature 519, 344-348. doi: $10.1038 /$ nature 14283

Brown, K. J., and Power, M. J. (2013). "Charred particle analyses," in The Encyclopedia of Quaternary Science (Amsterdam: Elsevier), 716-729.

Broxton, P. D., Zeng, X., Sulla-Menashe, D., and Troch, P. A. (2014). A global land cover climatology using MODIS data. J. Appl. Meteorol. Climatol. 53, 1593-1605. doi: 10.1175/JAMC-D-13-0270.1
Burbridge, R. E., Mayle, F. E., and Killeen, T. J. (2004). Fifty-thousand-year vegetation and climate history of Noel Kempff Mercado National Park, Bolivian Amazon. Quat. Res. 61, 215-230. doi: 10.1016/j.yqres.2003.12.004

Burn, M. J., Mayle, F. E., and Killeen, T. J. (2010). Pollen-based differentiation of Amazonian rainforest communities and implications for lowland palaeoecology in tropical South America. Palaeogeogr. Palaeoclimatol. Palaeoecol. 295, 1-18. doi: 10.1016/j.palaeo.2010.05.009

Bush, M. B., Correa-Metrio, A., McMichael, C. H., Sully, S., Shadik, C. R., Valencia, B. G., et al. (2016). A 6900-year history of landscape modification by humans in lowland Amazonia. Quat. Sci. Rev. 141, 52-64. doi: 10.1016/j.quascirev.2016.03.022

Bush, M. B., Miller, M. C., De Oliveira, P. E., and Colinvaux, P. A. (2000). Two histories of environmental change and human disturbance in eastern lowland Amazonia. Holocene 5, 543-553. doi: 10.1191/095968300672647521

Bush, M. B., Silman, M. R., de Toledo, M. B., Listopad, C., Gosling, W. D., Williams, C., et al. (2007a). Holocene fire and occupation in Amazonia: records from two lake districts. Philos. Trans. R. Soc. Lond. B. Biol. Sci. 362, 209-18. doi: 10.1098/rstb.2006.1980

Bush, M. B., Silman, M. R., and Listopad, C. M. C. S. (2007b). A regional study of Holocene climate change and human occupation in Peruvian Amazonia. J. Biogeogr. 34, 1342-1356. doi: 10.1111/j.1365-2699.2007.01704.x

Campos, M. T., and Ehringhaus, C. (2009). Plant virtues are in the eyes of the beholders: a comparison of known palm uses among indigenous and folk communities of southwestern Amazonia. Eco. Bot. 57, 324-344. doi: 10.1663/ 0013-0001(2003)057[0324:PVAITE]2.0.CO;2

Carson, J. F., Whitney, B. S., Mayle, F. E., Iriarte, J., Prümers, H., Soto, J. D., et al. (2014). Environmental impact of geometric earthwork construction in pre-Columbian Amazonia. Proc. Natl. Acad. Sci. U.S.A. 111, 1-6. doi: $10.1073 /$ pnas.1321770111

Castree, N. (2015). The anthropocene: a primer for geographers. Geography 100, 66-75.

Certini, G., and Scalenghe, R. (2011). Anthropogenic soils are the golden spikes for the anthropocene. Holocene 21, 1269-1274. doi: 10.1177/0959683611408454

Clement, C. R. (1999). 1492 and the loss of Amazonian crop genetic resources. II. crop biogeography at contact. Econ. Bot. 53, 203-216.

Clement, C. R., Denevan, W. M., Heckenberger, M. J., Junqueira, A. B., Neves, E. G., Teixeira, W. G., et al. (2015). The domestication of Amazonia before European conquest. Proc. R. Soc. Lond. B Biol. Sci. 282, 1-9. doi: $10.1098 / \mathrm{rspb} .2015 .0813$

Clement, C. R., Klüppel, M. P., German, L. A., Soares de Almeida, S., Major, J., de Aragão, L. E., et al. (2009). "Diversidade Vegetal em Solos Antrópicos da Amazônia," in As Terras Pretas de Índio da Amazônia: Sua Caracterização e uso Deste Conhecimento na Criação de Novas Áreas, eds W. G. Teixeira, D. C. Kern, B. E. Madari, H. N. Lima, and W. I. Woods (Dordrecht: Springer), $146-161$.

Clement, C. R., McCann, J. M., and Smith, N. J. H. (2003). “Agrobiodiversity in Amazônia and its relationship with dark earths," in Amazonian Dark Earths, eds J. Lehmann, D. C. Kern, B. Glaser, and W. I. Woods (Dordrecht: Springer), 159-178.

Cochrane, M. A. (2003). Fire science for rainforests. Nature 421, 913-919. doi: $10.1038 /$ nature 01437

Cochrane M. A. (ed.). (2009). "Fire in the tropics," in Tropical Fire Ecology, Springer Praxis Books (Berlin: Springer), 1-23.

Cochrane, M. A., Alencar, A., Schulze, M. D., Souza, C. M., Nepstad, D. C., Lefebvre, P., et al. (1999a). Positive feedbacks in the fire dynamic of closed canopy tropical forests. Science 284, 1832-1835. doi: $10.1126 /$ science.284.5421.1832

Cochrane, M. A., and Ryan, K. C. (2009). "Fire and fire ecology: concepts and principles," in Tropical Fire Ecology, ed M. Cochrane (Berlin; Heidelberg: Springer), 25-62.

Cochrane, M. A., Schulze, M. D., and Mar, N. (1999b). Fire as a recurrent event in tropical forests of the eastern amazon: effects on forest structure, biomass, and species composition. Biotropica 31, 2-16. doi: 10.2307/2663955

Cordeiro, A. (2004). Floresta Nacional do Tapajós: Plano de Manejo. Belterra: IBAMA.

Croudace, I. W., Rindby, A., and Rothwell, R. G. (2006). ITRAX: description and evaluation of a new multi-function X-ray core scanner. Spec. Publ. Soc. Lond. 267, 51. doi: 10.1144/GSL.SP.2006.267.01.04 
Cruz, F. W., Vuille, M., Burns, S. J., Wang, X., Cheng, H., Werner, M., et al. (2009). Orbitally driven east-west antiphasing of South American precipitation. Nat. Geosci. 2, 210-214. doi: 10.1038/ngeo444

De Andrade, D. F. C., and De Carvalho, J. O. P. (2011). "Dinâmica da composição florística $\mathrm{E}$ da estrutura de uma floresta manejada, que sofreu incêndio acidental, na floresta nacional do Tapajós," in Anais Do I Seminário De Pesquisas Científicas Da Floresta Nacional Do Tapajós, ed D. F. C. de Andrade (Santarém: Anais/I Seminário de Pesquisas Científicas da Floresta Nacional do Tapajós), $1-117$.

Dean, W. E Jr. (1974). Determination of carbonate and organic matter in calcareous sediments and sedimentary rocks by loss on ignition: comparison with other methods. J. Sediment. Res. 44, 242-248.

De Faria, B. L., Brando, P. M., Macedo, M. N., Panday, P. K., SoaresFilho, B. S., and Coe, M. T. (2017). Current and future patterns of fire-induced forest degradation in Amazonia. Environ. Res. Lett. 12:95005. doi: $10.1088 / 1748-9326 /$ aa69ce

De Toledo, M. B., and Bush, M. B. (2007). A mid-Holocene environmental change in Amazonian savannas. J. Biogeogr. 34, 1313-1326. doi: 10.1111/j.1365-2699.2006.01606.x

Denevan, W. (2001). Cultivated Landscapes of Native Amazonia and the Andes. New York, NY: Oxford University Press.

Denevan, W. M. (1992). The pristine myth: the landscape of the Americas in 1492. Ann. Assoc. Am. Geogr. 82, 369-385. doi: 10.1111/j.1467-8306.1992.tb01965.x

Denevan, W. M. (1995). 2 Prehistoric agricultural methods as models for sustainability. Adv. Plant Pathol. 11, 21-43. doi: 10.1016/S0736-4539(06)80004-8

de Souza, N. B., Junqueira, A. B., Struik, P. C., Stomph, T., and Clement, C. R. (2017). The role of fertile anthropogenic soils in the conservation of native and exotic agrobiodiversity in Amazonian homegardens. Agrofor. Syst. 1, 1-12 doi: 10.1007/s10457-017-0137-y

Downey, S. S., Haas, W. R., and Shennan, S. J. (2016). European neolithic societies showed early warning signals of population collapse. Proc. Natl. Acad. Sci. U.S.A. 113, 9751-9756. doi: 10.1073/pnas.1602504113

Elias, M., Mühlen, G. S., McKey, D., Roa, A. C., and Tohme, J. (2004). Genetic diversity of traditional South American landraces of cassava (Manihot esculenta Crantz): an analysis using microsatellites. Econ. Bot. 58, 242-256. doi: 10.1663/ 0013-0001(2004)058[0242:GDOTSA]2.0.CO;2

Erickson, C. L., and Balée, W. (2006). "The historical ecology of a complex landscape in bolivia," in Time and Complexity in Historical Ecology: Studies in the Neotropical Lowlands, eds W. Balee and C. L. Erickson (New York, NY: Columbia University Press), 187-233.

Eriksson, J., Söderström, M., and Isendahl, C. (2016). Properties of Amazonian Dark Earths at Belterra Plateau, Pará, Brazil. Beyond Waters Archaeol. Environ. Hist. Amaz. Inland. GOTARC Ser. A Gothenbg. Archaeol. Stud. 6, 87-98.

Faegri, K., and Iversen, J. (1989). Textbook of Pollen Analysis. (New York, NY: John Wiley).

Faith, D. P., Minchin, P. R., and Belbin, L. (1987). Compositional dissimilarity as a robust measure of ecological distance. Vegetatio 69, 57-68. doi: $10.1007 / \mathrm{BF} 00038687$

Fraser, J. A., Junqueira, A. B., Kawa, N. C., Moraes, C. P., and Clement, C. R. (2011). Crop diversity on anthropogenic dark earths in central Amazonia. Hum. Ecol. 39, 395-406. doi: 10.1007/s10745-011-9405-z

Gatti, L. V., Gloor, M., Miller, J. B., Doughty, C. E., Malhi, Y., Domingues, L. G., et al. (2014). Drought sensitivity of Amazonian carbon balance revealed by atmospheric measurements. Nature 506, 76. doi: 10.1038/nature12957

German, L. (2003). "Ethnoscientific understandings of Amazonian Dark Earths," in Amazonian Dark Earths: Origin Properties Management, eds J. Lehmann, D. C. Kern, B. Glaser, and W. I. Wodos (Dordrecht: Springer Netherlands), 179-201.

Glaser, B., and Woods, W. I. (2004). Amazonian Dark Earths: Explorations in Space and Time. Berlin: Springer.

Goldberg, A., Mychajliw, A. M., and Hadly, E. A. (2016). Post-invasion demography of prehistoric humans in South America. Nature 532, 232-235. doi: $10.1038 /$ nature 17176

Gomes, D. C. (2001). "Santarém: symbolism and power in the Tropical Forest," in Unknown Amazon, eds C. McEwam, C. Barreto, and E. Neves (London: The British Museum Press), 134-155.

Gomes, D. C. (2011). Cronologia e conexões culturais na Amazônia: as sociedades formativas na região de Santarém, PA. Rev. Antropol. 54, 268-314. doi: 10.11606/2179-0892.ra.2011. 38595
Gomes, D. M. C. (2017). Politics and ritual in large villages in Santarém, lower Amazon, Brazil. Cambridge Archaeol. J. 27, 275-293. doi: 10.1017/S0959774316000627

Grimm, E. C. (1987). CONISS: A Fortran 77 program for stratigraphically constrained cluster analysis by the method of the incremental sum of squares. Comput. Geosci. 13, 13-35. doi: 10.1016/0098-3004(87)90022-7

Hanelt, P., Báttner, R., and Mansfeld, R. (2001). Mansfeld's Encyclopedia of Agricultural and Horticultural Crops (Except Ornamentals). Berlin: Springer.

Heckenberger, M., and Neves, E. G. (2009). Amazonian archaeology. Annu. Rev. Anthropol. 38, 251-266. doi: 10.1146/annurev-anthro-091908-164310

Higuera, P. E., Brubaker, L. B., Anderson, P. M., Feng, S. H., and Brown, T. A. (2009). Vegetation mediated the impacts of postglacial climate change on fire regimes in the south-central Brooks Range, Alaska. Ecol. Monogr. 79, 201-219. doi: 10.1890/07-2019.1

Higuera, P. E., Gavin, D. G., Bartlein, P. J., and Hallett, D. J. (2010). Peak detection in sediment-charcoal records: impacts of alternative data analysis methods on fire-history interpretations. Int. J. Wildl. Fire 19, 996. doi: 10.1071/ WF09134

Higuera, P., Peters, M., Brubaker, L., and Gavin, D. (2007). Understanding the origin and analysis of sediment-charcoal records with a simulation model. Quat. Sci. Rev. 26, 1790-1809. doi: 10.1016/j.quascirev.2007.03.010

Hijmans, R. J., Cameron, S. E., Parra, J. L., Jones, P. G., and Jarvis, A. (2005) Very high resolution interpolated climate surfaces for global land areas. Int. J. Climatol. 25, 1965-1978. doi: 10.1002/joc.1276

Holst, I., Moreno, J. E., and Piperno, D. R. (2007). Identification of teosinte, maize, and Tripsacum in Mesoamerica by using pollen, starch grains, and phytoliths. Proc. Natl. Acad. Sci. U.S.A. 104, 17608-17613. doi: 10.1073/pnas.0708736104

Huber, O. (1995a). "Geographical and physical features," in Flora of the Venezuelan Guayana, eds P. E. Berry, B. K. Holst, and K. Yatskievych (St. Louis, MO: Missouri Botanical Garden), 1-62.

Huber, O. (1995b). "Vegetation," in Flora of the Venezuelan Guayana, eds P. E. Berry, B. K. Holst, and K. Yatskievych (St. Louis, MO: Missouri Botanical Garden), 97-160.

Iriarte, J. (2016). Investigating Amazonian Dark Earths as agro-ecosystems and their impact on the regional landscapes of the Lower Amazon. Beyond Waters, $71-87$.

Iriarte, J. (2017). "Un futuro sostenible para la Amazonia: lecciones de la arqueología," in Tropical Forest Conservation. Long-Term Processes of Human Evolution, Cultural Adaptations and Consumption Patterns, ed N. Sanz (Paris: UNESCO), 140-161.

Jackson, G. (1974). Cryptogeal germination and other seedling adaptations to the burning of vegetation in savanna regions: the origin of the pyrophytic habit. New Phytol. 73, 771-780. doi: 10.1111/j.1469-8137.1974.tb01305.x

Jakovac, C. C., Bongers, F., Kuyper, T. W., Mesquita, R. C. G., and Peña-Claros, M. (2016). Land use as a filter for species composition in Amazonian secondary forests. J. Veg. Sci. 27, 1104-1116. doi: 10.1111/jvs.12457

Junqueira, A. B., Levis, C., Bongers, F., Peña-Claros, M., Clement, C. R., Costa, F., et al. (2017). Response to comment on "Persistent effects of pre-Columbian plant domestication on Amazonian forest composition.” Science 358, 1-2. doi: 10.1126/science.aan 8837

Junqueira, A. B., Shepard, G. H., and Clement, C. R. (2010). Secondary forests on anthropogenic soils in Brazilian Amazonia conserve agrobiodiversity. Biodivers. Conserv. 19, 1933-1961. doi: 10.1007/s10531-0109813-1

Junqueira, A. B., Shepard, G. H., and Clement, C. R. (2011). Secondary forests on anthropogenic soils of the Middle Madeira River: valuation, local knowledge, and landscape domestication in Brazilian Amazonia. Econ. Bot. 65, 85-99. doi: 10.1007/s12231-010-9138-8

Junqueira, A. B., Souza, N. B., Stomph, T. J., Almekinders, C. J. M., Clement, C. R., and Struik, P. C. (2016). Soil fertility gradients shape the agrobiodiversity of Amazonian homegardens. Agric. Ecosyst. Environ. 221, 270-281. doi: 10.1016/j.agee.2016.01.002

Kahn, F. (1987). The distribution of palms as a function of local topography in Amazonian terra-firme forests. Cell. Mol. Life Sci. 43, 251-259. doi: $10.1007 /$ BF01945548

Kahn, F., and de Granville, J.-J. (1992). Palms in Forest Ecosystems of Amazonia. Berlin: Springer.

Kato, M. (1998). Fire-Free Land Preparation as an Alternative to Slash-And-Burn Agriculture in the Bragantina Region, Eastern Amazon: Crop Performance and Phosphorus Dynamics. Göttingen: Cuvillier Verlag. 
Ledru, M-P., Mourguiart, P., Ceccantini, G., and Turcq, B. (2002). Tropical climates in the game of two hemispheres revealed by abrupt climatic change. Geology 30, 275-278. doi: 10.1130/0091-7613(2002)030<0275:TCITGO >2.0.CO;2

Lehmann, J., da Silva, J. P., Steiner, C., Nehls, T., Zech, W., and Glaser, B. (2003a). Nutrient availability and leaching in an archaeological anthrosol and a ferralsol of the Central Amazon basin: fertilizer, manure and charcoal amendments. Plant Soil 249, 343-357. doi: 10.1023/A:1022833116184

Lehmann, J., Kern, D. C., Glaser, B., and Woods, W. I. (2003b). Amazonian Dark Earths: Origin Properties Management. Amsterdam: Springer Netherlands.

Le Page, Y., Morton, D., Corinne, H., Ben, B.-L., Cardoso Pereira, J. M., Hurtt, G., et al. (2017). Synergy between land use and climate change increases future fire risk in Amazon forests. Earth Syst. Dyn. Discuss. 8, 1-19. doi: 10.5194/esd-2017-55

Levis, C., Costa, F. R., Bongers, F., Peña-Claros, M., Clement, C. R., Junqueira, A. B., et al. (2017). Persistent effects of pre-columbian plant domestication on Amazonian forest composition. Science 355, 925-931. doi: 10.1126/science.aal0157

Levis, C., Flores, B. M., Moreira, P. A., Luize, B. G., Alves, R. P., Franco-Moraes, J., et al. (2018). How people domesticated Amazonian Forests. Front. Ecol. Evol. 5:171. doi: 10.3389/fevo.2017.00171

Levis, C., de Souza, P. F., Schietti, J., Emilio, T., Pinto, J. L. P., Clement C. R. et al. (2012). Historical human footprint on modern tree species composition in the purus-madeira interfluve, Central Amazonia. PLoS ONE 7:e48559. doi: 10.1371/journal.pone.0048559

Lins, J., Lima, H. P., Baccaro, F. B., Kinupp, V. F., Shepard, J.r, Glenn, H., et al. (2015). Pre-Columbian floristic legacies in modern homegardens of Central Amazonia. PLoS ONE 10:e0127067. doi: 10.1371/journal.pone.0127067

MacDonald, T. (2010). Urban-Rural Migration, Livelihood Change and Cultural Identity Among Smallholder Populations in Western Para, Brazil. Michigan State University: ProQuest Dissertations Publishing.

Maezumi, S. Y., Alves, A., Robinson, M., de Souza, J. G., Levis, C., Barnett, R. L., et al. (2018). The legacy of 4,500 years of polyculture agroforestry in the eastern Amazon. Nat. Plants doi: 10.1038/s41477-018-0205-y

Maezumi, S. Y., Power, M. J., Mayle, F. E., McLauchlan, K. K., and Iriarte, J. (2015). Effects of past climate variability on fire and vegetation in the cerrãdo savanna of the Huanchaca Mesetta, NE Bolivia. Clim. Past 11, 835-853. doi: 10.5194/cp-11-835-2015

Maezumi, S. Y., Whitney, B. S., Mayle, F. E., Gregorio de Souza, J., and Iriarte, J. (2017). Reassessing climate and pre-columbian drivers of paleofire activity in the Bolivian Amazon. Quat. Int. 3, 1-14. doi: 10.1016/j.quaint.2017.11.053

Major, J., Steiner, C., Ditommaso, A., Falcao, N. P. S., and Lehmann, J. (2005). Weed composition and cover after three years of soil fertility management in the central Brazilian Amazon: compost, fertilizer, manure and charcoal applications. Weed Biol. Manage. 5, 69-76. doi: 10.1111/j.1445-6664.2005.00159.x

Malhi, Y., Meir, P., and Brown, S. (2002). Forests, carbon and global climate. Philos. Trans. R. Soc. London. Ser. A Math. Phys. Eng. Sci. 360, 1567-1591. doi: 10.1098/rsta.2002.1020

Marengo, J. A., Tomasella, J., Alves, L. M., Soares, W. R., and Rodriguez, D. A. (2011). The drought of 2010 in the context of historical droughts in the Amazon region. Geophys. Res. Lett. 38, 1-5. doi: 10.1029/2011GL047436

Marengo, J. A., Nobre, C. A., Tomasella, J., Oyama, M. D., Sampaio de Oliveira, G., de Oliveira, R., et al. (2008). The Drought of Amazonia in 2005. J. Clim. 21, 495-516. doi: 10.1175/2007JCLI1600.1

Marland, G., Boden, T. A., and Andres, R. J. (2008). "Global, regional, and national fossil fuel CO2 emissions," in Trends: A Compendium of Data on Global Change (Oak Ridge, TN: Carbon Dioxide Information Analysis Center, Oak Ridge National Laboratory, U.S. Department of Energy).

Marlon, J. R., Bartlein, P. J., Carcaillet, C., Gavin, D. G., Harrison, S. P., Higuera, P. E., et al. (2008). Climate and human influences on global biomass burning over the past two millennia. Nat. Geosci. 1, 697-702. doi: 10.1038/ngeo313

McCune, B., and Grace, J. B. (2002). Analysis of Ecological Communities. Gleneden Beach, OR: MjM Software Design.

McMichael, C. H., Feeley, K. J., Dick, C. W., Piperno, D. R., and Bush, M. B. (2017). Comment on "Persistent effects of pre-columbian plant domestication on Amazonian forest composition." Science. 358, 1-2. doi: $10.1126 /$ science.aan 8347
McMichael, C. H., Piperno, D. R., Neves, E. G., Bush, M. B., Almeida, F. O., Mongeló, G., et al. (2015). Phytolith assemblages along a gradient of ancient human disturbance in Western Amazonia. Front. Ecol. Evol. 3:141. doi: 10.3389/fevo.2015.00141

Montoya, E., and Rull, V. (2011). Gran Sabana fires (SE Venezuela): a paleoecological perspective. Quat. Sci. Rev. 30, 3430-3444. doi: 10.1016/j.quascirev.2011.09.005

Montoya, E., Rull, V., and Nogu,é, S. (2011a). Early human occupation and land use changes near the boundary of the Orinoco and the Amazon basins (SE Venezuela): Palynological evidence from El Paují record. Palaeogeogr. Palaeoclimatol. Palaeoecol. 310, 413-426. doi: 10.1016/j.palaeo.2011.08.002

Montoya, E., Rull, V., Stansell, N. D., Abbott, M. B., Nogué, S., Bird, B. W., et al. (2011b). Forest - savanna - morichal dynamics in relation to fire and human occupation in the southern Gran Sabana (SE Venezuela) during the last millennia. Quat. Res. 76, 335-344. doi: 10.1016/j.yqres.2011. 06.014

Montoya, E., Rull, V., Stansell, N. D., Bird, B. W., Nogu,é, S., Vegas-Vilarrúbia, T., et al. (2011c). Vegetation changes in the neotropical gran sabana (Venezuela) around the Younger Dryas chron. J. Quat. Sci. 26, 207-218. doi: 10.1002 /jqs. 1445

Morcote-Ríos, G., and Bernal, R. (2001). Remains of palms (Palmae) at archaeological sites in the New World: a review. Bot. Rev. 67, 309-350. doi: 10. 1007/BF02858098

Morcote Ríos, G., Cabrera Becerra, G., Mahecha Rubio, D., Franky Calvo, C. E., and Cavalier, F., I. (1998). Las palmas entre los grupos cazadores-recolectores de la Amazonia Colombiana. Caldasia 20, 57-74.

Nepstad, D., Lefebvre, P., Lopes da Silva, U., Tomasella, J., Schlesinger, P., Solorzano, L., et al. (2004). Amazon drought and its implications for forest flammability and tree growth: A basin-wide analysis. Glob. Change Biol. 10, 704-717. doi: 10.1111/j.1529-8817.2003.00772.x

Neves, E. G., Petersen, J. B., Bartone, R. N., and Augusto Da Silva, C. (2003). "Historical and socio-cultural origins of Amazonian Dark Earth,"in Amazonian Dark Earths: Origin Properties Managemen, eds J. Lehmann, D. C. Kern, B. Glaser, and W. I. Wodos (Dordrecht: Springer), 29-50.

Nimuendajú, Nimuendajú, C. (1948). Os Tapajó, 93-106.

Nimuendajú, C. (2004). In Pursuit of a Past Amazon: Archaeological Researches in the Brazilian Guyana and in the Amazon Region. Göteborg: Elanders Infologistik.

Novello, V. F., Cruz, F. W., Karmann, I., Burns, S. J., Stríkis, N. M., Vuille, M., et al. (2012). Multidecadal climate variability in Brazil's Nordeste during the last 3000 years based on speleothem isotope records. Geophys. Res. Lett. 39, 1-6. doi: 10.1029/2012GL053936

Nowaczyk, N. R. (2001). "Logging of magnetic susceptibility," in Tracking Environmental Change Using Lake Sediments, eds J. P. Smol, H. J. B. Birks, and W. M. Last (Potsdam: Springer), 155-170.

Oguntunde, P. G., Fosu, M., Ajayi, A. E., and Van De Giesen, N. (2004). Effects of charcoal production on maize yield, chemical properties and texture of soil. Biol. Fertil. Soils 39, 295-299. doi: 10.1007/s00374-0030707-1

Oksanen, J., Blanchet, F. G., Friendly, M., Kindt, R., Legendre, P., McGlinn, D., et al. (2017). Vegan: Community Ecology Package.

Palace, M. W., McMichael, C. N. H., Braswell, B. H., Hagen, S. C., Bush, M. B. Neves, E., et al. (2017). Ancient Amazonian populations left lasting impacts on forest structure. Ecosphere 8:e02035. doi: 10.1002/ecs2.2035

Pausas, J. G., and Keeley, J. E. (2009). A burning story: The role of fire in the history of life. Bioscience 59, 593-601. doi: 10.1525/bio.2009. 59.7.10

Phillips, O. L., Aragão, L. E., Lewis, S. L., Fisher, J. B., Lloyd, J., López-González, G., et al. (2009). Drought sensitivity of the Amazon Rainforest. Science 323, 1344-1347. doi: 10.1126/science.1164033

Power, M. J., Marlon, J., Ortiz, N., Bartlein, P. J., Harrison, S. P., Mayle, F. E., et al. (2008). Changes in fire regimes since the last glacial maximum: an assessment based on a global synthesis and analysis of charcoal data. Clim. Dyn. 30, 887-907. doi: 10.1007/s00382-007-0334-x

Quintero-Vallejo, E., Peña-Claros, M., Bongers, F., Toledo, M., and Poorter, L. (2015). Effects of Amazonian Dark earths on growth and leaf nutrient balance of tropical tree seedlings. Plant Soil 396, 241-255. doi: $10.1007 /$ s11104-015-2558-6 
Ray, D., Nepstad, D., and Moutinho, P. (2005). Micrometeorological and canopy controls of fire susceptibility in a forested amazon landscape. Ecol. Appl. 15, 1664-1678. doi: 10.1890/05-0404

Reimer, P. J., Bard, E., Bayliss, A., Beck, J. W., Blackwell, P. G., Bronk Ramsey, C., et al. (2013). IntCal13 and marine13 radiocarbon age calibration curves 0-50,000 years cal BP. Radiocarbon 55, 1869-1887. doi: 10.2458/azu_js_rc.55.16947

Reynolds, R., Belnap, J., Reheis, M., Lamothe, P., and Luiszer, F. (2001). Aeolian dust in Colorado plateau soils: nutrient inputs and recent change in source. Proc. Natl. Acad. Sci. U.S.A. 98, 7123-7127. doi: 10.1073/pnas.121094298

Roberts, P., Hunt, C., Arroyo-Kalin, M., Evans, D., and Boivin, N. L. (2017). The deep human prehistory of global tropical forests and its relevance for modern conservation. Nat. Plants 3, 1-9. doi: 10.1038/nplants.2017.93

Roosevelt, A. C. (1999). The development of prehistoric complex societies: Amazonia, a tropical forest. Archeol. Pap. Am. Anthropol. Assoc. 9, 13-33. doi: 10.1525/ap3a.1999.9.1.13

Roosevelt, A. C. (2013). The Amazon and the anthropocene: 13,000 years of human influence in a tropical rainforest. Anthropocene 4, 69-87. doi: 10.1016/j.ancene.2014.05.001

Roosevelt, A. C., Lima da Costa, M., Lopes Machado, C., Michab, M., Mercier, N., Valladas, H., et al. (1996). Paleoindian cave dwellers in the Amazon: the peopling of the Americas. Science 272, 373-384. doi: $10.1126 /$ science. 272.5260 .373

Ruddiman, W. F. (2003). The anthropogenic greenhouse era began thousands of years ago. Clim. Change 3, 261-293. doi: 10.1023/B:CLIM.0000004577.17928.fa

Rull, V. (1992). Successional patterns of the gran sabana (Southeastern Venezuela) vegetation during the last 5000 years, and its responses to climatic fluctuations and fire. J. Biogeogr. 19, 329-338. doi: 10.2307/2845455

Rull, V., and Montoya, E. (2014). Mauritia flexuosa palm swamp communities: natural or human-made? A palynological study of the Gran Sabana region (northern South America) within a neotropical context. Quat. Sci. Rev. 99, 17-33. doi: 10.1016/j.quascirev.2014.06.007

Rull, V., Montoya, E., Nogué, S., Vegas-Vilarrúbia, T., and Safont, E. (2013). Ecological palaeoecology in the neotropical Gran Sabana region: long-term records of vegetation dynamics as a basis for ecological hypothesis testing. Perspect. Plant Ecol. Evol. Syst. 15, 338-359. doi: 10.1016/j.ppees.2013.07.004.

Schaan, D. (2010). Salvamento Arqueológico do Sítio PA-ST-42: Porto de Santarém. Belém: Relatório Final.

Schaan, D. P. (2012). "Sacred geographies of ancient Amazonia: historical ecology of social complexity," in New Frontiers in Historical Ecology, eds W. Balee and C. Crumley (Walnut Creek, CA: Left Coast Press) 132-142.

Schaan, D., Pärssinen, M., Saunaluoma, S., Ranzi, A., Bueno, M., and Barbosa, A. (2012). New radiometric dates for Precolumbian (2000-700 BP) earthworks in western Amazonia, Brazil. J. F. Archaeol. Archaeol. 37, 132-142. doi: 10.1179/0093469012Z.00000000012

Schmidt, M. J., Rapp Py-Daniel, A., de Paula Moraes, C., Valle, R. B. M., Caromano, C. F., Texeira, W. G., et al. (2014). Dark earths and the human built landscape in Amazonia: a widespread pattern of anthrosol formation. J. Archaeol. Sci. 42, 152-165. doi: 10.1016/J.JAS.2013.11.002

Schroth, G., Coutinho, P., Moraes, V. H. F., and Albernaz, A. L. (2003). Rubber agroforests at the Tapajós river, Brazilian Amazon-environmentally benign land use systems in an old forest frontier region. Agric. Ecosyst. Environ. 97, 151-165. doi: 10.1016/S0167-8809(03)00116-6

Shennan, S., Downey, S. S., Timpson, A., Edinborough, K., Colledge, S., Kerig, T., et al. (2013). Regional population collapse followed initial agriculture booms in mid-Holocene Europe. Nat. Commun. 4, 1-8. doi: 10.1038/ncomms3486

Smith, B. D., and Zeder, M. A. (2013). The onset of the anthropocene. Anthropocene 4, 8-13. doi: 10.1016/j.ancene.2013.05.001

Smith, N. J. H. (1980). Anthrosols and human carrying capacity in Amazonia. Ann. Assoc. Am. Geogr. 70, 553-566.

Soares-Filho, B., Silvestrini, R., Nepstad, D., Brando, P., Rodrigues, H., Alencar, A., et al. (2012). Forest fragmentation, climate change and understory fire regimes on the Amazonian landscapes of the Xingu headwaters. Landsc. Ecol. 27, 585-598. doi: 10.1007/s10980-012-9723-6

Sombroek, W. G. (1966). Amazon Soils. Wageningen: Centre for agricultural publications and documentation.

Steiner, C., Teixeira, W. G., Lehmann, J., Nehls, T., de Macêdo, J. L. V., Blum, W. E. H., et al. (2007). Long term effects of manure, charcoal and mineral fertilization on crop production and fertility on a highly weathered Central Amazonian upland soil. Plant Soil 291, 275-290. doi: 10.1007/s11104-007-9 193-9

Stenborg, P., Schaan, D. P., and Lima, M. A. (2012). Precolumbian land use and settlement pattern in the Santarém region, lower Amazon. Amazônica 4, 222-250. doi: 10.18542/amazonica.v4i1.886

ter Steege, H., Pitman, N. C., a, Sabatier, D., Baraloto, C., Salomão, R. P., Guevara, J. E., et al. (2013). Hyperdominance in the Amazonian tree flora. Science 342:1243092. doi: 10.1126/science. 1243092

Timpson, A., Colledge, S., Crema, E., Edinborough, K., Kerig, T., Manning, K., et al. (2014). Reconstructing regional population fluctuations in the European neolithic using radiocarbon dates: a new case-study using an improved method. J. Archaeol. Sci. 52, 549-557. doi: 10.1016/j.jas.2014.08.011

Turney, C. S. M., Palmer, J., Maslin, M. A., Hogg, A., Fogwill, C. J., Southon, J., et al. (2018). Global peak in atmospheric radiocarbon provides a potential definition for the onset of the anthropocene epoch in 1965. Sci. Rep. 8, 3293. doi: 10.1038/s41598-018-20970-5

Urrego, D. H., Bush, M. B., Silman, M. R., Niccum, B. A., De La Rosa, P., McMichael, C. H., et al. (2013). Holocene fires, forest stability and human occupation in south-western Amazonia. J. Biogeogr. 40, 521-533. doi: $10.1111 /$ jbi.12016

Urrego, D. H., Hooghiemstra, H., Rama-Corredor, O., Martrat, B., Grimalt, J. O., Thompson, L., et al. (2016). Millennial-scale vegetation changes in the tropical andes using ecological grouping and ordination methods. Clim. Past 12, 697-711. doi: 10.5194/cp-12-697-2016

Walker, J. H. (2011). Amazonian Dark Earth and ring ditches in the Central Llanos de Mojos, Bolivia. Cult. Agric. Food Environ. 33, 2-14. doi: 10.1111/j.2153-9561.2011.01043.x

Wang, X., Edwards, R. L., Auler, A. S., Cheng, H., Kong, X., Wang, Y., et al. (2017). Hydroclimate changes across the Amazon lowlands over the past 45,000 years. Nature 541, 204-207. doi: 10.1038/nature20787

Waters, C. N., Zalasiewicz, J., Summerhayes, C., Barnosky, A. D., Poirier, C., Gałuszka, A., et al. (2016). The anthropocene is functionally and stratigraphically distinct from the Holocene. Science 351, 1-26. doi: $10.1126 /$ science.aad 2622

Watling, J., Iriarte, J., Mayle, F. E., Schaan, D., Pessenda, L. C., Loader, N. J., et al. (2017). Impact of pre-columbian "geoglyph" builders on Amazonian forests. Proc. Natl. Acad. Sci. U.S.A. 114, 1868-1873. doi: 10.1073/pnas.16143 59114

Weinstein, B. (1983). The Amazon Rubber Boom, 1850-1920. Stanford, CA: Stanford University Press.

Welch, J. R., Brondízio, E. S., Hetrick, S. S., and Coimbra, C. E. (2013). Indigenous burning as conservation practice: neotropical savanna recovery amid agribusiness deforestation in central brazil. PLoS ONE 8:e81226. doi: 10.1371 /journal.pone.0081226

Whitlock, C., and Larsen, C. (2002). "Charcoal as a fire proxy," in Tracking Environmental Change Using Lake Sediments, eds J. P. Smol, H. J. B. Birks, W. M. Last (Dordrecht: Springer), 75-97.

Whitney, B. S., Rushton, E. A., Carson, J. F., Iriarte, J., and Mayle, F. E. (2012). An improved methodology for the recovery of Zea mays and other large crop pollen, with implications for environmental archaeology in the Neotropics. Holocene 22, 1087-1096. doi: 10.1177/0959683612 441842

Wirth, C., Messier, C., Bergeron, Y., Frank, D., and Fankhänel, A. (2009). "Oldgrowth forest definitions: a pragmatic view,"in Old-Growth Forests: Function, Fate and Value, eds C. Wirth, G. Gleixner, and M. Heimann (Berlin; Heidelberg: Springer), 11-33.

Woods, W. I., Denevan, W. M., and Rebellato, L. (2013). "How many years do you get for couterfeitting a paradise?," in Soils, Climate and Society Archaeological Investigations in Ancient America, eds S. E. Hayes and J. D. Wingard (Denver, CO: University Press of Colorado), 1-20.

Woods, W. I., and McCann, J. M. (1999). The anthropogenic origin and persistence of Amazonian dark earths. Yearb. Conf. Lat. Am. Geogr. 25, 7-14.

Woods, W. I., Teixeira, W. G., Lehmann, J., Steiner, C., WinklerPrins, A., and Rebellato, L. (2009). Amazonian Dark Earths: Wim Sombroek's Vision. Berlin: Springer.

Wright, H. E. (1967). A square-rod piston sampler for lake sediments. J. Sediment. Res. 37, 975-976. 
Yeang, H. Y., and Chevallier, M.-H. (1999). Range of hevea Brasiliensis pollen dispersal estimated by esterase isozyme markers. Ann. Bot. 84, 681-684. doi: 10.1006/anbo.1999.0959

Zahid, H. J., Robinson, E., and Kelly, R. L. (2016). Agriculture, population growth, and statistical analysis of the radiocarbon record. Proc. Natl. Acad. Sci. U.S.A. 113, 931-935. doi: 10.1073/pnas.15176 50112

Zalasiewicz, J., Waters, C. N., Williams, M., Barnosky, A. D., Cearreta, A., Crutzen, P., et al. (2015). When did the Anthropocene begin? A mid-twentieth century boundary level is stratigraphically optimal. Quat. Int. 385, 196-203. doi: 10.1016/j.quaint.2014.11.045
Conflict of Interest Statement: The authors declare that the research was conducted in the absence of any commercial or financial relationships that could be construed as a potential conflict of interest.

Copyright $(2018$ Maezumi, Robinson, de Souza, Urrego, Schaan, Alves and Iriarte. This is an open-access article distributed under the terms of the Creative Commons Attribution License (CC BY). The use, distribution or reproduction in other forums is permitted, provided the original author(s) and the copyright owner(s) are credited and that the original publication in this journal is cited, in accordance with accepted academic practice. No use, distribution or reproduction is permitted which does not comply with these terms. 